\title{
COMPOSITION, STRUCTURE AND DYNAMICS OF ARTHROPOD COMMUNITIES IN A RICE AGRO-ECOSYSTEM
}

\author{
C.N.B. Bambaradeniya ${ }^{1}$ and J.P. Edirisinghe ${ }^{2}$ \\ ${ }^{1}$ IUCN - The World Conservation Union, Asia Regional Office, Sri Lanka \\ ${ }^{2}$ Department of Zoology, University of Peradeniya, Sri Lanka \\ Accepted 12 June 2008
}

\begin{abstract}
The study on terrestrial arthropod communities in rice agro-ecosystems was conducted in Bathalagoda, Sri Lanka. A total of 342 arthropod species was documented comprising 282 species of insects in 90 families and 17 orders and 60 species of arachnids in 14 families. Eight taxa new to Sri Lanka are reported. Majority of the insects documented were hymenopterans, dominated by bees and ants. Based on feeding habits, majority of the arthropods recorded were predators (149 species), dominated by spiders. However, in the rice field proper, abundance of phytophagous rice pests was higher than that of predators. Density fluctuations of predators and parasitoids were positively correlated. Species richness and diversity of terrestrial arthropods increased gradually with crop age, but declined following application of pesticides. Species diversity $\left(\mathrm{H}^{\prime}\right)$ of terrestrial arthropods during vegetative, reproductive and grain ripening stages and the fallow period were significantly different. Diversity of terrestrial arthropods in the field proper positively correlated with crop age and height of the rice plant, and in field bunds with the weed cover. Findings indicate that a stable relationship could be maintained between rice insect pests and their arthropod natural enemies through minimal biocide applications and manipulation of weed cover in the rice agroecosystem.
\end{abstract}

Key Words: Rice fields, arthropods, diversity, species richness, pests, natural enemies

\section{INTRODUCTION}

\section{Origin and history of rice agro-ecosystems}

Rice cultivation is thought to be the oldest form of intensive agriculture by man (Fernando, 1977). Cultivation of the crop probably dates back to the earliest age of man and, long before the era for which there is historical evidence, rice was a staple food and the first cultivated crop in Asia (Grist, 1965). Historical evidence indicates that both tropical (indica) and temperate (sinica) races of Oryza sativa were being cultivated in parts of China at least 7000 years ago (Chang, 1985).

Rice has been grown in Sri Lanka from time immemorial. It is generally believed that rice cultivation in Sri Lanka was started by IndoAryan immigrants before about 540 B.C where it was probably grown as a dryland crop (Grist, 1965; Perera, 1980). According to published sources, rice is cultivated on about 780,000 ha (Panabokke, 1996) in the island, which is approximately $12 \%$ of the total land area. Based on the water regime, rice fields in Sri Lanka fall into three major categories; those under major irrigation schemes (41\%), minor irrigation schemes (25\%) and rainfed ricelands (34\%)
(Gunatilleke and Somasiri, 1995). In most areas where adequate water is present, rice is cultivated during two annual cropping seasons; the Maha (October - February) and Yala (April - August) seasons. The former is recognised as the major cropping season, as it receives more rainfall from the north east monsoon producing rain throughout the island, while the latter is the minor cropping season (Panabokke, 1996).

\section{Arthropod communities in the rice agro- ecosystem}

Irrigated rice fields, being agronomically managed wetland ecosystems with a high degree of environmental heterogeneity operating on a short temporal scale, harbour a rich and varied fauna (Heckman, 1979). The fauna is dominated by micro, meso and macro invertebrates (especially arthropods) inhabiting the soil, water and vegetation sub-habitats of the rice fields. The terrestrial arthropod community in rice fields consists mainly of insects and spiders which largely inhabit the vegetation (rice plants and weeds), and the soil surface. The occurrence of terrestrial arthropods in the rice ecosystem is mainly influenced by the rice plants. The different communities of terrestrial arthropods in the rice field include rice pests, their natural enemies (predators and parasitoids) and other

*Corresponding author’s email: cnb@iucnsl.org 
non-rice pest insects that inhabit or visit the vegetation. The composition of the arthropod communities is known to change with the growth of the rice crop (Heong et al., 1991).

Dale (1994) in his comprehensive account on the biology and ecology of insect pests of rice states that over 800 species of insects damage the rice plant in several ways, although the majority of them cause minor damage. Although the species composition of terrestrial arthropod pests and natural enemies in rice fields throughout the world is relatively well documented, there are only a few studies that examine the overall terrestrial arthropod community in rice fields. Among them, the work of Heong et al., (1991) and Schoenly et al., (1995) carried out in the Philippines provides an insight into the arthropod communities and their guild structure in irrigated rice fields. A pioneering study by Settle et al., (1996) conducted in Java demonstrated the existence of a mechanism in tropical irrigated rice systems that support high levels of natural biological control. In Sri Lanka, studies on terrestrial arthropods in rice fields are confined to surveys documenting the distribution of major rice insect pests and their natural enemies (Otake et al., 1976; Rajendran and Devarajah, 1990; Kobayashi et al., 1991; Kobayashi et al., 1995), while no attempts have been made to document the structure and diversity of terrestrial arthropod communities in rice fields. Such a study carried out over successive rice cultivation cycles would provide useful information for the development of effective and safe integrated rice pest management strategies.

The overall objective of the study was to determine the contribution of the terrestrial arthropod community to the rice field ecosystem. The specific objectives were to determine the (i) species composition, structure and abundance of arthropod guilds (ii) distribution of arthropod species in different habitats of the rice field comprising the rice field proper, and bunds (iii) dynamics of the arthropod community from planting to harvest of the crop, from land preparation to fallow and in relation to agronomic practices carried out during the cultivation cycle.

\section{MATERIALS AND METHODS}

\section{Study site}

The study was conducted at Bathalagoda, in the Kurunegala district, located in the Intermediate Zone of Sri Lanka, $7^{\circ} 30^{\prime} \mathrm{N}, 80^{\circ} 28^{\prime} \mathrm{E}$,
$100 \mathrm{~m}$ a.s.l. elevation. The rice field surveyed (approximately 0.4 ha in extent; field proper to bund area ratio 20:1; eight rectangular plots) was managed by the Rice Research and Development Institute (RRDI) at Bathalagoda, for the purpose of producing paddy seed.

\section{Establishment of the rice crop and associated agronomic practices}

During a single year, two rice crops were established in the rice field during Yala and Maha seasons. The rice cultivar planted during the Yala season was BG - 450 (duration 4 - 4.5 months), while BG - 38 (duration 5 - 5.5 months) was planted during the Maha season. Crop establishment in surrounding fields was carried out in an asynchronized (staggered) manner. The field was harrowed and ploughed by tractor, and kept under standing water (up to $10 \mathrm{~cm}$ depth) for about two weeks. Irrigation water was supplied to the field from the nearby Bathalagoda tank at regular intervals (every 3-4 days) at the initial stages of cultivation. The rice crop was established by manual transplanting of three week old seedlings, at a regular spacing of $25 \mathrm{~cm}$ x $25 \mathrm{~cm}$.

The fertilizer regime included the application of crude fertilizer (4 Kg Nitrogen $+25 \mathrm{Kg}$ Phosphorous $+6 \mathrm{Kg}$ Potassium) to the nursery 23 days prior to sowing, and Nitrogen fertilizer (4 Kg Urea) 5 - 10 days after sowing. Basal application - crude fertilizer (100 Kg / ha) consisting of $4 \mathrm{Kg} \mathrm{N}+36 \mathrm{Kg} \mathrm{P}+45 \mathrm{Kg} \mathrm{K}$ was applied to the field 2-3 days before transplanting. At the maximum tillering stage - Nitrogen fertilizer (100 Kg of Urea per ha) was applied to the field. At the panicle initiation stage - top dressing material fertilizer (120 Kg per ha at the rate of $50 \mathrm{Kg} \mathrm{N}+10 \mathrm{Kg} \mathrm{K}$ ) was applied to the field. Weeds were managed in an intense manner, where the bunds were slashed manually 2-3 times per cycle, supplemented with a single weedicide (MCPA) application and manual weeding. Insecticides were applied to the rice crop at the nursery stage (Curator ${ }^{\circledR}$ - Carbofuran) during both cultivation cycles, while a broad-spectrum insecticide was applied at the grain ripening stage, only during the Maha cycle. The fallow period between two crops was short (2-3 weeks).

\section{Sampling of the terrestrial arthropod community}

Sampling of the terrestrial arthropod community was conducted to determine species composition, abundance and distribution in the different habitats of the rice field. Sampling was conducted over a 12 month period, encompassing 
two consecutive rice cultivation cycles (Yala and Maha ). Sampling was carried out at fortnightly intervals, where about four hours were spent in the field on each sampling day during the morning hours (0745 - 1145 h), covering each cultivation plot.

The terrestrial arthropod fauna consisting of insects and spiders inhabiting the rice field proper was sampled using a portable 'Blower-Vac' suction device (Arida and Heong, 1992) and the field bunds were sampled using a standard sweep net. For the use of the Blower-Vac in the rice field proper, a bottomless plastic bin (height: 65 $\mathrm{cm}$, diameter: $51 \mathrm{~cm}$, fitted with a nylon net on top) was placed at random towards the center of each plot to enclose seven rice hills (surface area $0.2 \mathrm{~m}^{2}$ ). The arthropods within the enclosed space; on rice plants, weeds and water / ground surface were sucked in by the Blower-Vac, and flushed into a container with $70 \%$ ethanol for storage. A total of 10 random samples were obtained (using a random digits table) on each sampling day. In order to ensure a uniform capture efficiency using the Blower-Vac device, usage time per sample was increased with increasing growth and age of the rice plant. The arthropods in the rice field bunds were sampled by taking 20 sweeps from the vegetation (weeds) while walking along a $20 \mathrm{~m}$ bund transect (one sweep / m) at each of five randomly selected locations (using numbered paper slots) on each sampling day. Arthropods collected in 20 sweeps were immediately sprayed with an insecticide $\left(\right.$ Baygon $^{\circledR}$ ) and put into labeled plastic containers with $70 \%$ ethanol. The weed cover along the sweep netted area of the bund was assessed on each sampling day using a 5 point scoring system : 1 = Few, scattered seedlings; 2 = Low, patchy weed cover; 3 = Moderate weed cover; 4 = Dense weed cover; 5 = Saturated and widespread weed cover. A total of 190 Blower-Vac samples and 95 sweep net samples were collected during the entire study period at fortnightly intervals from the rice field. In the laboratory each sample was sorted into different insect and spider taxa and counted.

\section{Identification of arthropod taxa and their subsequent assignment into guilds}

The insects and spiders collected from the rice fields using the two methods were identified and classified into the smallest possible taxa using available keys and guides for the different taxa. Barrion and Litsinger (1994) was used as a reference for rice pests, their predators and parasitoids. The Homoptera were further classified using the keys of Wilson and Claridge
(1991). The Lepidoptera pests and non-pests were identified using Nishida and Tori (1970) and D’Abreira (1998), respectively. The Odonata were identified using De Fonseka (1997). The Araneae were identified using Barrion and Litsinger (1995) and Tikader (1995).

The provisionally identified specimens of arthropods were confirmed by comparing with reference specimen collections held in the Smithsonian collection at the Department of Zoology, University of Peradeniya, collection at the Entomology Museum of the Horticultural Research and Development Institute (HORDI), Gannoruwa, collections at the Rice Research and Development Institute (RRDI), Bathalagoda and the reference insect collection of the National Museums, Colombo. The identity of certain specimens was further confirmed by local and overseas taxonomists. Voucher specimens were deposited at the Museum of the Department of Zoology, University of Peradeniya, Sri Lanka. Following the identification of the terrestrial arthropods collected from the rice and non-rice habitats, they were assigned to guilds (as accurately as possible) according to Moran and Southwood (1982) and Heong et al., (1991). These guilds were based on feeding habits and included phytophages (rice pests and non-rice pest visitors), predators, parasitoids and scavengers/ decomposers.

\section{Data analyses}

Data obtained on the abundance of pests, predators and parasitoids from the rice and nonrice habitats were compared using Means and Standard Error values (SE at 95\% confidence limits). The effect of different agronomic practices on the temporal abundance of different arthropod guilds was examined graphically.

The arthropod diversity and species richness in the rice field proper and the bunds were compared using ecological indices reviewed by Magurran (1988), calculated separately for each sample (Blower vac and sweep net) on each sampling day. The mean values of the two indices obtained for Yala and Maha cycles were statistically analysed using the SAS nested GLM Procedure (Littell et al., 1991). Using the pooled data from the two cycles, the diversity of arthropods at the three major growth stages of the rice crop (vegetative, reproductive, ripening) and on harvest (fallow period) was analysed using the SAS Nested GLM Procedure. Correlation and regression analysis using the SAS system (Freund and Littell, 1991) were carried out to determine significant relationships among (a) the density of 
different arthropod guilds, (b) fluctuations in arthropod diversity with crop age days after transplanting (DAT), height of the rice plant, and (c) variation in arthropod diversity in field bunds with change in weed cover.

\section{RESULTS}

\section{Species composition of terrestrial arthropods}

A rich terrestrial arthropod fauna comprising 282 species of insects in 90 families and 17 Orders; 60 species of arachnids in 14 families constituting a total of 342 arthropod species were recorded from the rice field during the study. A detailed list of the taxa recorded, their food habits and their specific habitat in the rice ecosystem is provided in Appendix 1.

Of the terrestrial arthropods documented, eight taxa consisting of one insect species and seven spider species are new records for Sri Lanka. The newly recorded insect is Brachystegus decoratus (Turner) (Hymenoptera: Sphecidae), while the spiders included the two species, Tetragnatha javana (Thorell), Tetragnatha nitens (Audouin) and five species belonging to the genera Dyschiriognatha., Steatoda, Gnathonarium, Arctosa, and Thanatus. Of the total arthropods recorded, the three species of water surface dwelling heteropterans; Microvelia douglasi, Mesovelia spp. and Hydrometra greenii, were confined to the rice habitat during the aquatic phase, while 74 species were exclusively confined to the vegetation on the non-rice, bund habitat. These consisted mainly of lepidopterans belonging to the families Papilionidae, Nymphalidae, Lycaenidae and Pieridae and hymenopterans belonging to the Family Apidae.

\section{Taxonomic composition of terrestrial arthropods}

Majority of the insect species documented from the rice field belonged to the Order Hymenoptera (81 species in 26 families), dominated by bees and ants (Fig.1). The second largest insect order recorded was Lepidoptera consist of 58 species, in seven families, dominated by the Family Nymphalidae (24 spp.). Coleoptera was the third largest insect order, with 40 species in eight families. Carabids (18 spp.) were dominant among the Coleoptera. Orders Homoptera and Heteroptera together included 38 species in 17 families. The homopterans were dominated by the Family Cicadellidae (10 spp.), while the heteropterans were dominated by the Family Pentatomidae (seven spp.). In Order Diptera, of the 21 species in 11 families, Tabanidae (five spp.) was the dominant family. The Odonata included 19 species in five families, dominated by the Family Libellulidae (nine spp.). The Orthoptera included 10 species in four families, where the Acrididae (six spp.) was the dominant family. The Collembola included four species, in three families. The Orders Strepsiptera, Thysanoptera and Mantodea included two species each. The remaining five insect Orders (Dermaptera, Phasmatoidea, Blattoidea, Neuroptera and Isoptera) included one species each. The arachnids consisted of 59 species of Araneae (spiders) in 13 families and one species of Acari (mites). Amongst the spiders, Family Araneidae had the highest number of species (12), closely followed by the Family Tetragnathidae (11 spp.).

\section{Terrestrial arthropod guilds}

Terrestrial arthropods recorded from the rice ecosystem were assigned to guilds based on food habits of the species. Accordingly, five arthropod guilds were identified. Majority were predators (149 spp.) (Table 1 and Appendix 1), where spiders were the dominant predatory group with 59 species followed by Coleoptera and Hymenoptera, each with 25 species and Odonata with 19 species. Of the 130 species of phytophagous insects recorded, the majority (76 spp.) were visitors and insects associated with weeds in the rice field. The phytophagous guild was dominated by Lepidoptera (50 spp.) followed by Hymenoptera with 15 bees species. The remaining phytophagous insects comprised 55 species of rice pests represented by sap feeders, leaf feeders, stem feeders and root feeders (Table 1). Homopterans (14 spp.) were the dominant phytophagous pest group, closely followed by heteropteran pests (10 spp.). The parasitoid guild comprising 46 species of insects was dominated by hymenopterans (40 spp.). The scavenger/decomposer guild contained the fewest number of species (16 spp.), dominated by the Order Diptera (10 spp.), followed by Collembola (four spp.). The overall species composition reflects a high richness of arthropod natural enemies (predators and parasitoids) in relation to the rice insect pests, where the natural enemy to pest ratio is 3.5:1. A majority of the parasitoids recorded attack rice insect pests. 


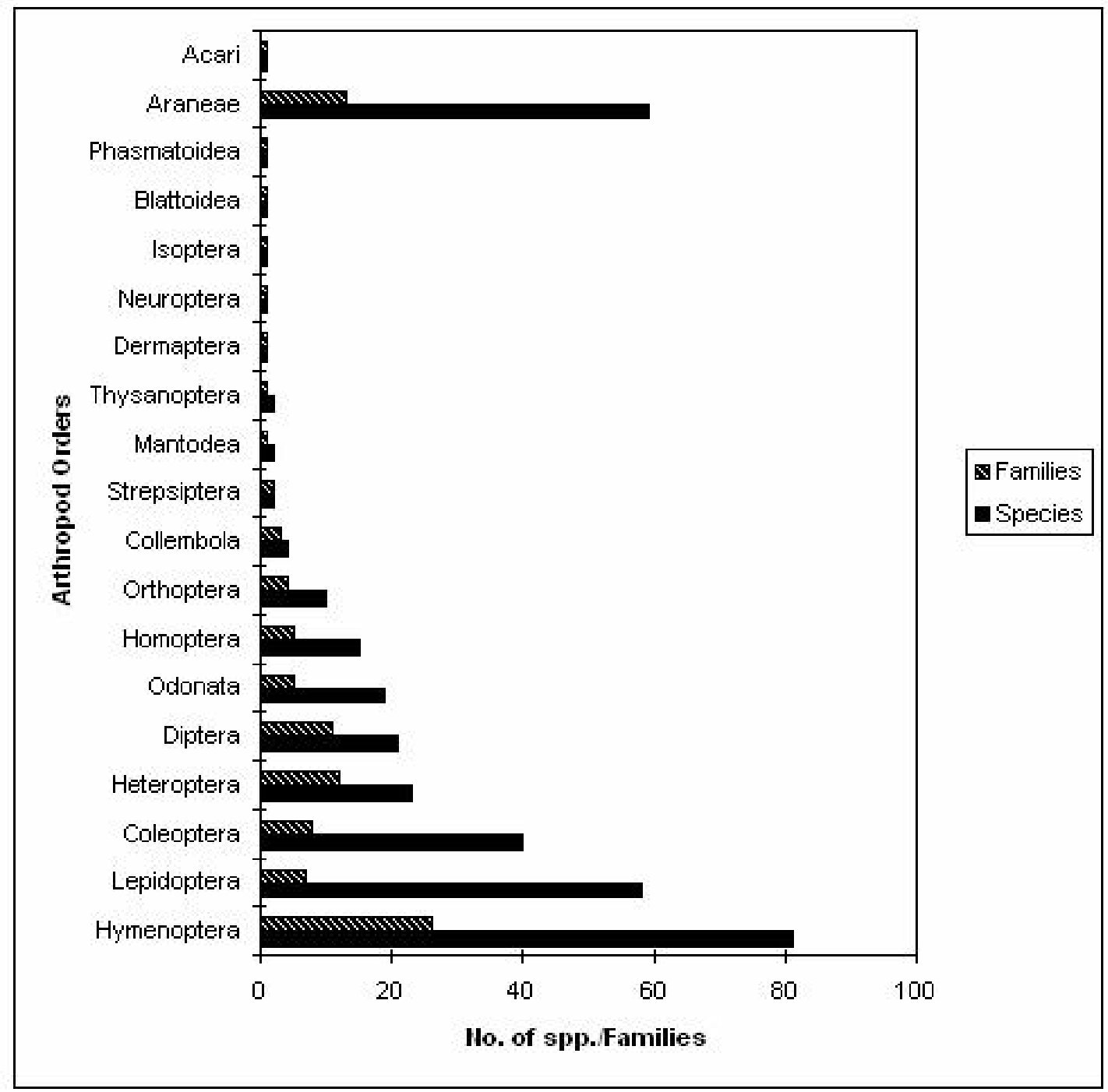

Figure 1. Species composition and taxonomy of terrestrial arthropods in a rice ecosystem, in Bathalagoda, Sri Lanka.

\begin{abstract}
Relative abundance of arthropods in different guilds

Rice habitat: Based on Blower-vac sample counts, the relative abundance of arthropod species in different guilds was calculated. Abundance of phytophagous rice pests was higher than that of the predators, constituting about one third of all arthropods in each guild (Table 2). Homoptera was the dominant group of phytophagous pests, followed by Diptera. The relative composition of Homoptera was higher during the Maha cycle than Yala cycle. Among
\end{abstract}

the predators, spiders were the most abundant group, constituting more than half of the predators. Coleopterans were the second most abundant predatory group. Predatory orthopterans showed a considerable increase in relative abundance during the Maha cycle. The next most abundant guild was the scavengers, dominated by the Collembola. The relative abundance of scavengers was lower during the Maha cycle than the Yala cycle. In the parasitoid guild, similar relative abundance levels were recorded during both Yala and Maha cycles. The phytophage visitor guild in the rice habitat was the least abundant arthropod guild. 
Among the phytophagous pests, the Homoptera were generally dominated by the Family Cicadellidae (Table 3). The abundance of delphacids showed a considerable increase during the Maha cycle. Among the cicadellids, the green leafhoppers (Nephotettix spp.) were the predominant species, while the delphacids were dominated by the white-backed plant hopper (Sogatella furcifera). Spiders which formed the major predatory group were dominated by the
Family Therididae, constituting more than half the spiders. The abundance of the mirid bug Cyrtorhinus lividipennis, which is known to prey upon the eggs and nymphs of Homopteran pests (especially the delphacids), showed a considerable increase during the Maha cycle (Table 3). The parasitoids were dominated by the hymenopteran Family Mymaridae. The trichogrammatids on the other hand showed a considerable increase during the Maha cycle.

Table 1. Number of terrestrial arthropod species (families) under different feeding guilds recorded from the rice fields in Bathalagoda.

\begin{tabular}{|c|c|c|c|c|c|c|c|c|}
\hline $\begin{array}{l}\text { 믈 } \\
\text { Order }\end{array}$ & 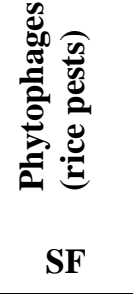 & DFM & SB & $\mathbf{R F}$ & 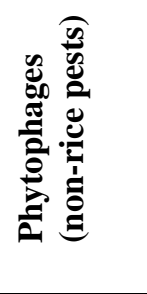 & 竞 & 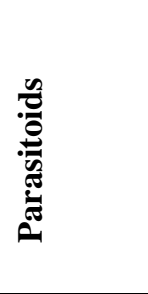 & 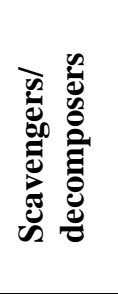 \\
\hline Acari & - & - & - & - & - & $1(1 \mathrm{~F})$ & - & - \\
\hline Araneae & - & - & - & - & - & 59 (13F) & - & - \\
\hline Blattoidea & - & - & - & - & - & - & - & $1(1 \mathrm{~F})$ \\
\hline Coleoptera & - & $6(1 \mathrm{~F})$ & - & $3(2 F)$ & $5(2 \mathrm{~F})$ & $25(4 \mathrm{~F})$ & - & $1(1 \mathrm{~F})$ \\
\hline Collembola & - & - & - & - & - & - & - & $4(3 F)$ \\
\hline Dermaptera & - & - & - & - & - & $1(1 \mathrm{~F})$ & - & - \\
\hline Diptera & - & $5(4 \mathrm{~F})$ & - & - & - & $2(2 F)$ & $4(2 F)$ & $10(4 \mathrm{~F})$ \\
\hline Heteroptera & $10(3 F)$ & - & - & - & $4(4 \mathrm{~F})$ & $9(7 F)$ & - & - \\
\hline Homoptera & $14(4 \mathrm{~F})$ & - & - & - & $1(1 \mathrm{~F})$ & - & - & - \\
\hline Isoptera & - & - & - & $1(1 \mathrm{~F})$ & - & - & - & - \\
\hline Hymenoptera & - & $1(1 \mathrm{~F})$ & - & - & $15(4 \mathrm{~F})$ & $25(5 F)$ & $40(17 \mathrm{~F})$ & - \\
\hline Lepidoptera & - & $4(3 \mathrm{~F})$ & $4(1 F)$ & - & $50(5 F)$ & - & - & - \\
\hline Mantodea & - & - & - & - & - & $2(1 \mathrm{~F})$ & - & - \\
\hline Neuroptera & - & - & - & - & - & $1(1 \mathrm{~F})$ & - & - \\
\hline Odonata & - & - & - & - & - & $19(5 F)$ & - & - \\
\hline Orthoptera & - & $6(1 \mathrm{~F})$ & - & - & - & $4(3 F)$ & - & - \\
\hline Phasmatoidea & - & - & - & - & - & $1(1 \mathrm{~F})$ & - & - \\
\hline Strepsiptera & - & - & - & - & - & - & $2(2 F)$ & - \\
\hline Thysanoptera & $1(1 \mathrm{~F})$ & - & - & - & $1(1 \mathrm{~F})$ & - & - & - \\
\hline Total & $25(8 F)$ & $22(10 \mathrm{~F})$ & $4(1 F)$ & $4(3 F)$ & $76(17 F)$ & $149(44 F)$ & $46(21 F)$ & $16(9 F)$ \\
\hline
\end{tabular}

Note: Pests: SF - Sap feeders; DFM - Defoliators/miners; SB - Stem borers; RF - Root feeders F - Families 
Table 2. Relative composition (\% Mean \pm SE per sample) of arthropod taxa in different guilds in the rice habitat. (Based on blower-vac sampling)

\begin{tabular}{lcc}
\hline Guild/Order & Yala $(\boldsymbol{n}=\mathbf{9 0})$ & Maha $(\boldsymbol{n}=\mathbf{1 0 0})$ \\
\hline Phytophages (Pests) & $\mathbf{2 9 . 1}( \pm \mathbf{4 . 4 )}$ & $\mathbf{3 6 . 6}( \pm \mathbf{4 . 3 )}$ \\
Homoptera & $58.5( \pm 7.3)$ & $60.1( \pm 6.1)$ \\
Diptera & $19.2( \pm 6.8)$ & $14.2( \pm 4.7)$ \\
Heteroptera & $5.1( \pm 2.4)$ & $12.7( \pm 5.0)$ \\
Orthoptera & $6.9( \pm 3.9)$ & $5.1( \pm 2.4)$ \\
Thysanoptera & $6.4( \pm 3.7)$ & $4.9( \pm 2.4)$ \\
Coleoptera & $2.1( \pm 1.4)$ & $1.6( \pm 2.2)$ \\
Lepidoptera & $1.8( \pm 1.3)$ & $3.3( \pm 3.1)$ \\
& $\mathbf{1 . 2}( \pm \mathbf{0 . 9})$ & $\mathbf{0 . 2}( \pm \mathbf{0 . 3})$ \\
Phytophages(Visitors) & $\mathbf{2 5 . 4 ( \pm 3 . 4 )}$ & $\mathbf{3 0 . 1}( \pm 3.7)$ \\
Predators & $60.1( \pm 7.8)$ & $58.8( \pm 6.7)$ \\
Araneae & $17.0( \pm 6.1)$ & $20.2( \pm 5.5)$ \\
Coleoptera & $6.8( \pm 4.8)$ & $4.3( \pm 3.4)$ \\
Heteroptera & $5.6( \pm 3.9)$ & $3.0( \pm 2.6)$ \\
Odonata & $4.6( \pm 2.3)$ & $1.6( \pm 1.7)$ \\
Acarina & $2.6( \pm 1.7)$ & $7.2( \pm 3.3)$ \\
Orthoptera & $2.7( \pm 2.7)$ & $2.0( \pm 1.8)$ \\
Diptera & $0.6( \pm 0.7)$ & $2.9( \pm 2.6)$ \\
Hymenoptera & $\mathbf{1 0 . 6}( \pm \mathbf{2 . 9})$ & $\mathbf{1 0 . 5}( \pm 2.1)$ \\
Parasitoids & $94.3( \pm 5.5)$ & $96.5( \pm 3.7)$ \\
Hymenoptera & $5.7( \pm 5.5)$ & $3.5( \pm 3.7)$ \\
Diptera & $\mathbf{3 3 . 7}( \pm 5.3)$ & $\mathbf{2 2 . 5}( \pm \mathbf{4 . 0 )}$ \\
Scavengers & $91.3( \pm 4.8)$ & $82.1( \pm 7.7)$ \\
Collembola & $8.7( \pm 4.8)$ & $17.9( \pm 7.7)$ \\
Diptera & &
\end{tabular}

n=number of samples

Non-rice bund habitats: Vegetation in the nonrice habitat or the field bunds was sampled for arthropods using the sweep net. Based on per sample counts (Mean \pm SE in 20 sweeps) of arthropods, the abundance of both phytophagous pests and predators was found to be similar in the bunds (Table 4). Orthoptera and Heteroptera were the dominant phytophagous pests, followed by Homoptera. Heteroptera showed a considerable increase in abundance during the Maha cycle. The predators were dominated by Araneae and Odonata (Table 4). Phytophage visitors were dominated by Heteroptera, followed by Hymenoptera. The parasitoids were dominated by Hymenoptera. The scavengers collected in the sweep nets were low in numbers, and consisted only of Diptera.

Of the heteropteran pests of rice, Leptocorisa oratorius was the most abundant species (Table 5). Homoptera were dominated by Cicadellidae. Among the spiders in bunds, Families Tetragnathidae and Oxyopidae were the most abundant groups. Of the other common predatory groups in the field bunds, Odonata were dominated by the damselflies belonging to the Family Coenagrionidae, while the Coleoptera were dominated by Coccinellidae. Hymenopteran parasitoids in the bunds were dominated by the Family Braconidae, followed by Chalcididae and Ichneumonidae. 
Table 3. Relative proportions (\%) of major arthropod species in different guilds during Yala and Maha cycles. (Based on Blower-vac sampling)

\begin{tabular}{|c|c|c|}
\hline Guild/Taxa & Yala $(\mathrm{n}=90)$ & Maha $(\mathrm{n}=100)$ \\
\hline \multicolumn{3}{|l|}{ Phytophages (Pests) } \\
\hline \multicolumn{3}{|l|}{ HOMOPTERA } \\
\hline Cicadellidae & 81.3 & 53.5 \\
\hline Nephotettix virescens & 35.4 & 41.0 \\
\hline N. nigropictus & 38.7 & 26.4 \\
\hline Recilia dorsalis & 10.8 & 19.9 \\
\hline Cofana spectra & 14.2 & 12.6 \\
\hline Delphacidae & 18.7 & 46.5 \\
\hline Nilaparvata lugens & 23.4 & 22.1 \\
\hline Sogatella furcifera & 76.6 & 77.9 \\
\hline \multicolumn{3}{|l|}{ HETEROPTERA } \\
\hline Leptocorisa oratorius & 79.0 & 89.7 \\
\hline Pentatomidae & 21.0 & 10.3 \\
\hline \multicolumn{3}{|l|}{ DIPTERA } \\
\hline Chironomidae & 81.7 & 28.3 \\
\hline Orseolea oryzae & 9.7 & 66.2 \\
\hline Muscidae & 7.3 & 4.0 \\
\hline \multicolumn{3}{|l|}{ ORTHOPTERA } \\
\hline Acrida exaltata & 68.0 & 71.4 \\
\hline \multicolumn{3}{|l|}{ Predators } \\
\hline \multicolumn{3}{|l|}{ HETEROPTERA } \\
\hline Cyrtorhinus lividipennis & 33.3 & 76.9 \\
\hline \multicolumn{3}{|l|}{ COLEOPTERA } \\
\hline \multicolumn{3}{|l|}{ Paederus alternans } \\
\hline Carabidae & 38.5 & 36.3 \\
\hline Coccinellidae & 34.6 & 36.3 \\
\hline ARANEAE & 27.0 & 27.8 \\
\hline \multicolumn{3}{|l|}{ Therididae } \\
\hline Araneidae & 50.5 & 53.0 \\
\hline Linyphiidae & 15.5 & 16.0 \\
\hline Tetragnathidae & 13.5 & 14.8 \\
\hline Lycosidae & 7.4 & 5.0 \\
\hline Salticidae & 5.7 & 5.7 \\
\hline Oxyopidae & 4.5 & 2.0 \\
\hline \multirow[t]{2}{*}{ Thomisidae } & 2.3 & 2.5 \\
\hline & 0.5 & 0.8 \\
\hline \multicolumn{3}{|l|}{ Parasitoids } \\
\hline Mymaridae & 39.3 & 39.0 \\
\hline Scelionidae & 23.3 & 18.2 \\
\hline Trichogrammatidae & 19.3 & 32.8 \\
\hline Braconidae & 8.0 & 2.5 \\
\hline Pteromalidae & 4.0 & 2.4 \\
\hline Diapriidae & 3.0 & 2.5 \\
\hline Ichneumonidae & 2.0 & 1.5 \\
\hline Eulophidae & 1.1 & 1.1 \\
\hline
\end{tabular}


Dynamics of arthropod guilds in relation to growth stage of rice plant

Rice habitat: Abundance patterns of pests and predators followed a general trend during both cycles (Fig. 2). During the early vegetative stage of the crop, abundance of phytophagous

pests was relatively higher than that of predators. The opposite trend was observed during the grain ripening stage where predator density was higher than pest density. Abundance of phytophagous pests increased rapidly and reached a peak between 25-45 days after transplanting (DAT). The predator built up was gradual and reached a peak between 90-120 DAT. The pattern of fluctuation of predators and parasitoids was similar, but at a lower abundance level. Parasitoid and predator abundance increased following an increase in phytophagous pests.

Application of an insecticide during the grain ripening stage in the Maha cycle resulted in a decrease in the abundance of phytophagous pests, predators and parasitoids. Thereafter, the number of pests increased faster than the natural enemies. Application of a weedicide in the Maha cycle resulted in a decline in the abundance of predators and parasitoids, but the phytophagous pests were not affected. With the harvest of the crop and the onset of the fallow period, phytophagous pests as well as their natural enemies declined in abundance.

The population of Collembola reached peak levels at a very early stage of a cycle, between 520 DAT (Fig. 3). Although a reduction in their density was observed after the early peak, their populations built up gradually with the progress of the crop cycle. However, with the application of weedicides and insecticides their density was reduced considerably. With the harvest of the crop, the density of collembolans was drastically reduced.

Table 4. Relative composition (mean \% \pm SE) of arthropod taxa in different guilds in non-rice bund habitat during Yala and Maha cycles (Based on sweep net collections).

\begin{tabular}{|c|c|c|}
\hline Guild/Order & Yala $(n=45)$ & $\operatorname{Maha}(n=50)$ \\
\hline Phytophages (Pests) & $38.4( \pm 5.0)$ & $43.0( \pm 6.7)$ \\
\hline Orthoptera & $42.2( \pm 10.0)$ & $29.2( \pm 8.8)$ \\
\hline Heteroptera & $24.7( \pm 9.7)$ & $52.5( \pm 10.3)$ \\
\hline Homoptera & $20.1( \pm 8.8)$ & $10.5( \pm 7.5)$ \\
\hline Coleoptera & $9.8( \pm 6.2)$ & $4.6( \pm 2.7)$ \\
\hline Lepidoptera & $3.3( \pm 3.1)$ & $2.5( \pm 2.0)$ \\
\hline Thysanoptera & 0.0 & $0.7( \pm 1.0)$ \\
\hline Diptera & 0.0 & 0.0 \\
\hline Phytophages (Visitors) & $12.7( \pm 4.3)$ & $7.3( \pm 2.4)$ \\
\hline Heteroptera & $45.9( \pm 13.7)$ & $50.0( \pm 15.6)$ \\
\hline Hymenoptera & $26.1( \pm 12.2)$ & $39.7( \pm 15.4)$ \\
\hline Lepidoptera & $15.6( \pm 11.6)$ & $7.2( \pm 8.5)$ \\
\hline Coleoptera & $12.4( \pm 9.1)$ & $3.1( \pm 6.1)$ \\
\hline Predators & $39.0( \pm 5.0)$ & $42.1( \pm 6.1)$ \\
\hline$\overline{\text { Araneae }}$ & $24.1( \pm 8.1)$ & $31.4( \pm 6.2)$ \\
\hline Odonata & $26.9( \pm 6.3)$ & $24.5( \pm 6.40$ \\
\hline Coleoptera & $19.5( \pm 7.3)$ & $16.4( \pm 6.8)$ \\
\hline Hymenoptera & $19.2( \pm 7.1)$ & $10.2( \pm 5.0)$ \\
\hline Orthoptera & $6.9( \pm 3.3)$ & $14.1( \pm 5.5)$ \\
\hline Heteroptera & $3.5( \pm 1.9)$ & $3.5( \pm 2.2)$ \\
\hline$\underline{\text { Parasitoids }}$ & $5.0( \pm 2.3)$ & $3.9( \pm 1.8)$ \\
\hline$\overline{\text { Hymenoptera }}$ & 100.0 & 100.0 \\
\hline Scavengers & $4.8( \pm 1.8)$ & $3.8( \pm 2.0)$ \\
\hline Diptera & 100.0 & 100.0 \\
\hline
\end{tabular}


Table 5. Relative proportions (\%) of major taxa in the non-rice bund habitat of the rice field during Yala and Maha cycles (Data from sweep net samples).

\begin{tabular}{|c|c|c|}
\hline Guild/Taxa & Yala $(n=45)$ & $\operatorname{Maha}(n=50)$ \\
\hline \multicolumn{3}{|l|}{ Phytophages (Pests) } \\
\hline \multicolumn{3}{|l|}{$\overline{\text { HOMOPTERA }}$} \\
\hline Cicadellidae & 91.5 & 87.0 \\
\hline Delphacidae & 8.5 & 13.0 \\
\hline \multicolumn{3}{|l|}{ HETEROPTERA } \\
\hline Leptocorisa oratorius & 90.0 & 94.0 \\
\hline Pentatomidae & 8.0 & 2.8 \\
\hline \multicolumn{3}{|l|}{ ORTHOPTERA } \\
\hline Acrida exaltata & 43.5 & 42.5 \\
\hline Oxya japonica & 32.5 & 34.3 \\
\hline \multicolumn{3}{|l|}{ Predators } \\
\hline \multicolumn{3}{|l|}{ HETEROPTERA } \\
\hline Reduviidae & 58.9 & 90.0 \\
\hline Miridae & 41.1 & 10.0 \\
\hline \multicolumn{3}{|l|}{ COLEOPTERA } \\
\hline Coccinellidae & 88.5 & 94.1 \\
\hline Micraspis discolor & 65.0 & 71.9 \\
\hline Carabidae & 11.5 & 5.9 \\
\hline \multicolumn{3}{|l|}{ ODONATA } \\
\hline Libellulidae & 25.5 & 21.7 \\
\hline Diplacodes trivialis & 37.5 & 38.5 \\
\hline Coenagrionidae & 70.5 & 69.5 \\
\hline Ceriagrion spp. & 46.1 & 65.2 \\
\hline \multicolumn{3}{|l|}{ HYMENOPTERA } \\
\hline Formicidae & 96.0 & 95.5 \\
\hline Solenopsis spp. & 65.2 & 45.8 \\
\hline \multicolumn{3}{|l|}{ ORTHOPTERA } \\
\hline Conocephalus longipennis & 70.0 & 57.1 \\
\hline Gryllidae & 28.0 & 41.0 \\
\hline \multicolumn{3}{|l|}{ ARANEAE } \\
\hline Tetragnathidae & 15.5 & 40.0 \\
\hline Oxyopidae & 37.5 & 29.6 \\
\hline Thomisidae & 20.1 & 3.0 \\
\hline Therididae & 7.8 & 3.0 \\
\hline Araneidae & 5.7 & 17.5 \\
\hline Salticidae & 3.1 & 5.2 \\
\hline Lycosidae & 6.2 & 0.8 \\
\hline Clubionidae & 3.6 & 0.5 \\
\hline Linyphiidae & 1.0 & 0.7 \\
\hline \multicolumn{3}{|l|}{ Parasitoids } \\
\hline \multicolumn{3}{|l|}{$\overline{\text { HYMENOPTERA }}$} \\
\hline Braconidae & 26.5 & 40.6 \\
\hline Chalcididae & 38.2 & 32.2 \\
\hline Ichneumonidae & 26.5 & 25.0 \\
\hline Others & 8.8 & 2.2 \\
\hline
\end{tabular}

$\mathrm{n}$ = sweep net replicates (with 20 sweeps /replicate) 

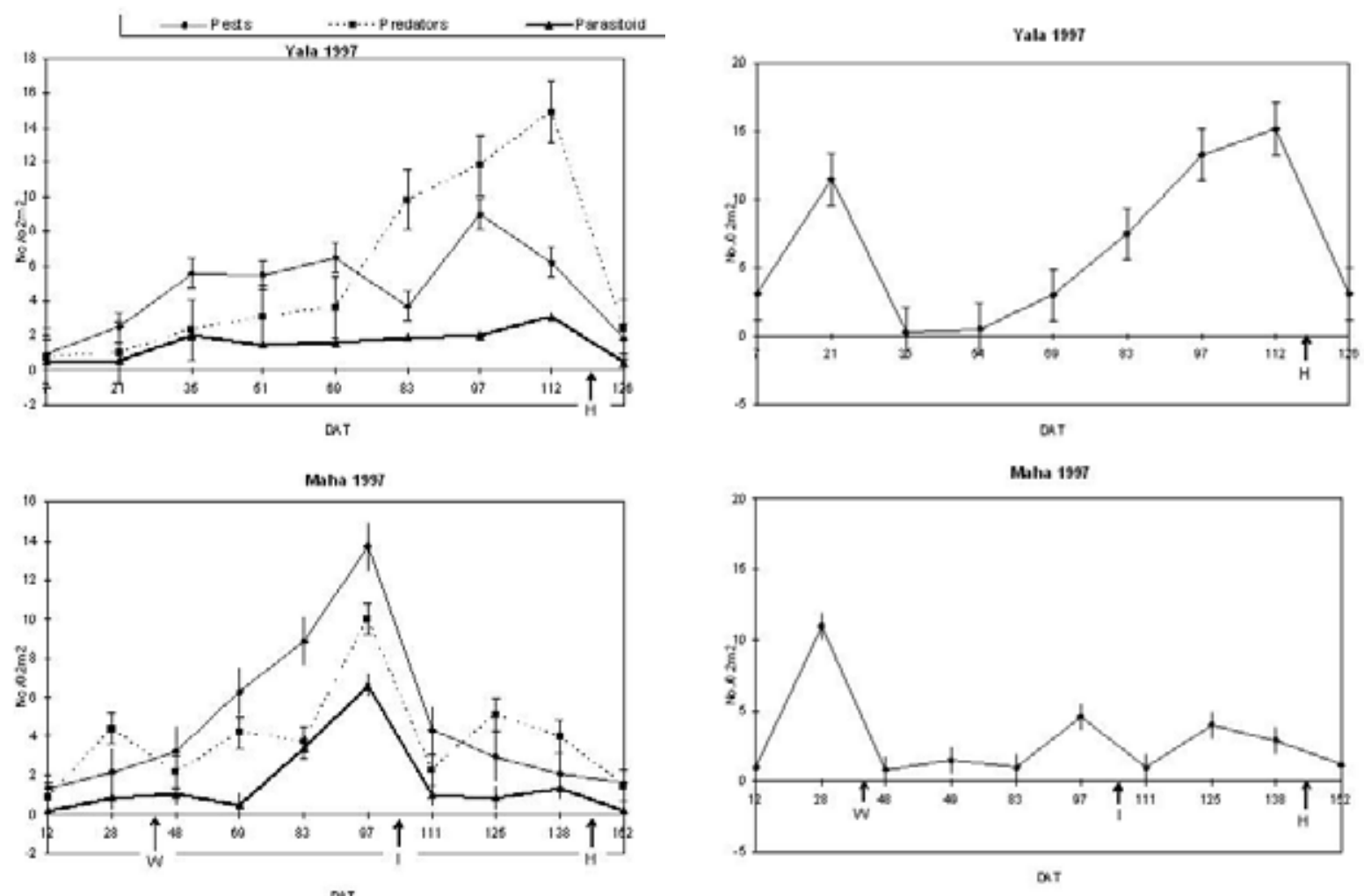

Figure 2. Temporal abundance patterns of pest phytophages, predators and parasitoids in the rice habitat, during the Yala and Maha 1997 cycles. (Data - Blower-vac samples) (DAT Days after transplanting, W - Weedicide application, I - Insecticidae application, H Crop harvest).
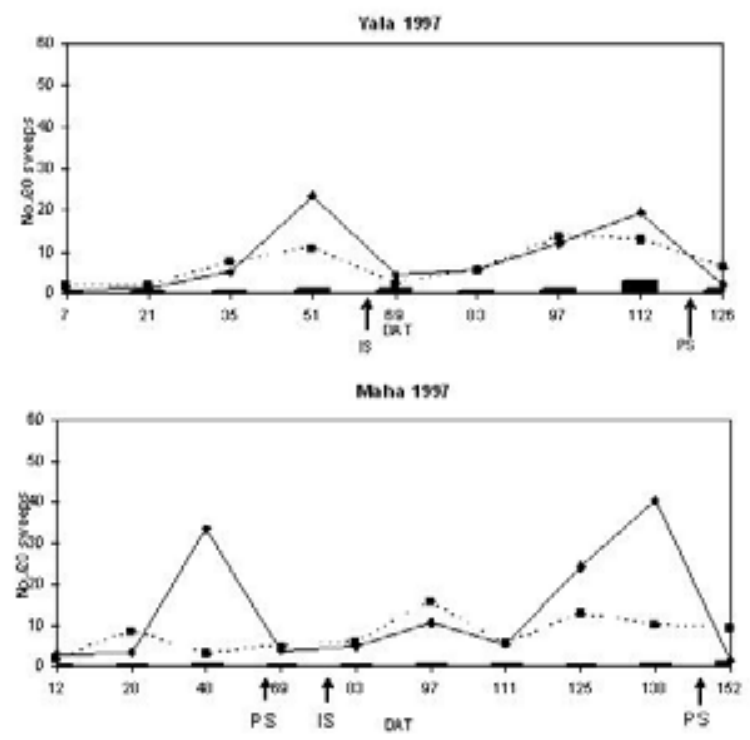

Figure 4. Temporal abundance patterns of pests, predators and parasitoids in the bund habitat, during Yala and Maha 1997cycles. (Data: Sweep net samples) (PS - Partial slashing; IS - Intense slashing; DAT - Days after transplanting).

Figure 3. Temporal abundance patterns of Collembola in the rice habitat during the Yala and Maha 1997 cycles. (Data - Blower-vac samples; I - Insecticide application, W Weedicide application, H - Crop harvest) (DAT - Days after transplanting). 
Non-rice bund habitat: In the bunds, arthropods were sampled using the sweep net. The trends in abundance patterns of phytophagous pests, predators and parasitoids in the field bunds (Fig. 4) were similar to those in the field proper. The densities of predators and parasitoids were found to fluctuate with the density of pests. The density of phytophagous pests was relatively higher than that of predators. Partial and intense slashing of the weed cover in bunds during the vegetative and mature stages of the rice crop resulted in a reduction in density of pests, predator and parasitoids. Intense slashing of weeds affected the predators more drastically than the pests.

\section{Relationships among arthropod guilds}

The density of predators recorded from the rice habitat correlated positively and significantly $(\mathrm{P}<0.05)$ with the density of pests (Table 6). The parasitoid density in the rice habitat also showed a highly significant $(\mathrm{P}<0.01)$ positive correlation with pest density. The predators recorded from the non-rice bund habitats also showed a highly significant $\quad(\mathrm{P}<0.01)$ positive correlation with pest density in bunds.

\section{Terrestrial arthropod diversity}

Spatial and temporal variation in arthropod species richness and diversity

The arthropod species richness and diversity was determined separately for the rice habitat and the non-rice habitat in order to examine their independent contributions. Furthermore, changes in these two parameters with time i.e., with the progress of the cultivation cycle and the growth of the rice plant was determined.

Rice habitat: The species richness diversity of terrestrial arthropods increased gradually with crop age in the Yala cultivation where pesticides were not applied after transplanting (Fig. 5). However, in the Maha cultivation, species richness and diversity were reduced after the application of a weedicide and an insecticide (Fig. 5). Following the harvest of the crop, terrestrial arthropods declined rapidly.

The mean species diversity (H') of terrestrial arthropods at the four major phenological stages of the rice crop, namely the vegetative stage, reproductive stage, ripening stage and at harvest (fallow period) were significantly different $(\mathrm{P}<0.05)$ (Table 7$)$. The highest diversity was recorded during the reproductive or grain ripening stages. However, the mean species diversity ( $\left.\mathrm{H}^{\prime}\right)$ and species richness $\left(\mathrm{N}_{0}\right)$ were not significantly different $(\mathrm{P}>0.05)$ between the two seasons.

Non-rice bund habitat: The species richness and diversity showed a marked reduction following partial and intense slashing of weed cover in bunds (Fig.6) and during the fallow period. As in the field proper, the mean species diversity ( $\left.\mathrm{H}^{\prime}\right)$ and species richness $\left(\mathrm{N}_{0}\right)$ in the field bunds, were not significantly different $(\mathrm{P}>0.05)$ between the two consecutive cycles.

Table 6. Comparison of pest, predator and parasitoid density obtained using the two sampling methods. (Pearson's coefficient (r) values)

\begin{tabular}{llc}
\hline Habitat & Correlated variables & Pearson's coefficient \\
\hline Field proper (rice habitat) & Predator / Pest & $0.3^{*}$ \\
& Parasitoid / Pest & $0.88^{* *}$ \\
Bunds (non-rice habitat) & Predator / Pest & $0.6^{* *}$ \\
\hline
\end{tabular}

$*(\mathrm{P}<0.05) ; * *(\mathrm{P}<0.01)$.

Table 7. Mean diversity (H') values of terrestrial arthropods at four stages of the Yala and Maha cycles. (Blower-vac sampling)

\begin{tabular}{llc}
\hline Stage/cycle & Yala & Maha \\
\hline 1.Vegetative & 1.32 & 1.61 \\
2. Reproductive & 1.99 & 2.34 \\
3. Ripening & 2.40 & 1.83 \\
4. Fallow period & 1.57 & 0.89 \\
\hline
\end{tabular}

P Cycle $>0.05$; P Stage $<0.01$ 

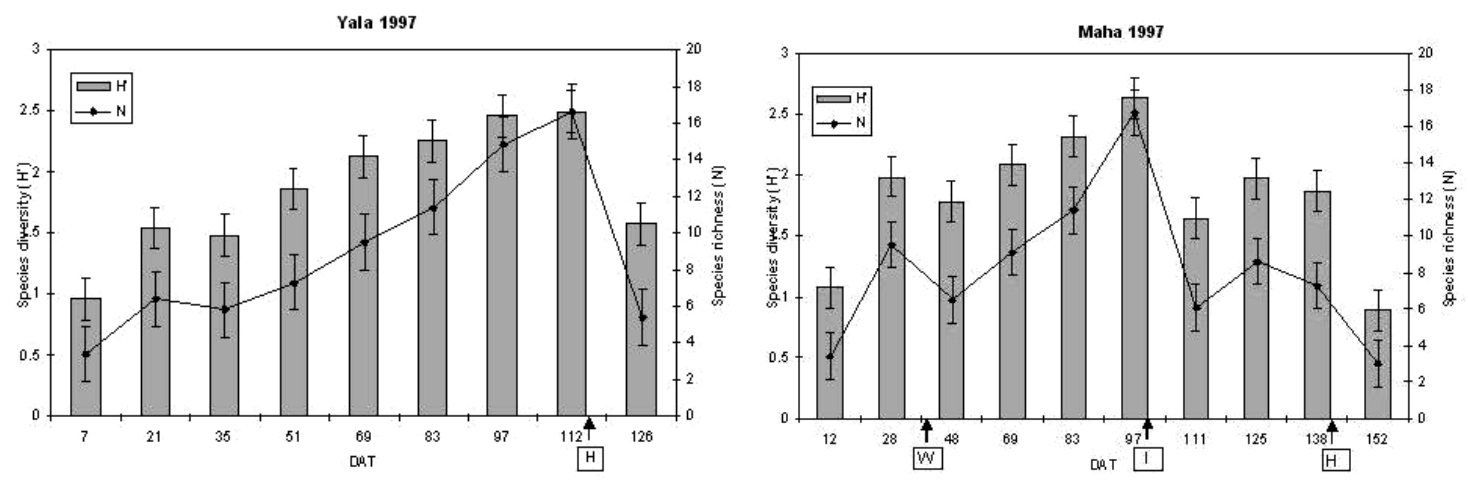

Figure 5. Temporal fluctuation pattern of arthropod species richness $(\mathrm{N})$ and diversity $\left(\mathrm{H}^{\prime}\right)$ in the rice habitat during the Yala and Maha 1997 cycles. (DAT - Days after transplanting; I Insecticide application; W - Weedicide application; H - Crop harvest).
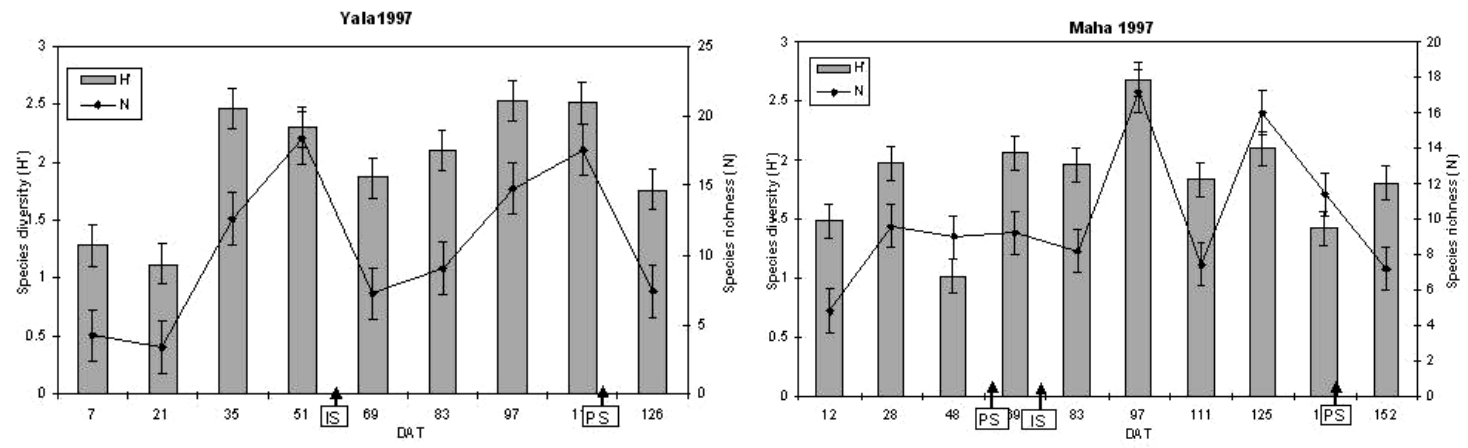

Figure 6. Temporal fluctuation pattern of arthropod species richness $(\mathrm{N})$ and diversity $\left(\mathrm{H}^{\prime}\right)$ in the non-rice bund habitat, during the Yala and Maha 1997cycles. (DAT - Days after transplanting; PS - Partial slashing of weeds, IS - Intense slashing of weeds).

\section{Arthropod diversity in relation to crop phenology and weed cover}

Using data from blower-vac and sweep net sampling obtained during Yala and Maha cycles, the relationship between terrestrial arthropod diversity (H') with crop age (DAT), rice plant height $(\mathrm{m})$ and \% weed cover in bunds were determined.. The mean height of the rice plants ranged from $0.18 \mathrm{~m}$ (at transplant) to $1.3 \mathrm{~m}$ (at harvest), depending on the rice cultivar. The weed cover in bunds during the sampling period ranged from a few scattered seedlings (score $=1$ ) at the beginning of each cultivation cycle, to a dense cover (score $=5$ ) towards the mature stage of the rice crop. Slashing of weeds in the bunds during the mid and latter stages of each cycle resulted in a reduction of the weed cover (score $=$ 1-2). The diversity of terrestrial arthropods in the field proper showed a highly significant positive relationship with crop age $(\mathrm{P}<0.01)$ and rice plant height $(\mathrm{P}<0.01)$. Correlation coefficients obtained indicated that $75 \%$ of the variation in arthropod diversity was attributed to crop age (Fig. 7) while the rice plant height alone accounted for $54 \%$ of the variation in arthropod diversity (Fig. 8). The diversity of arthropods in the field bunds was significantly related to the weed cover in bunds, where a polynomial model, while being significant $(\mathrm{P}<0.05)$, accounted for only $30 \%$ of the variation in arthropod diversity (Fig. 9). 


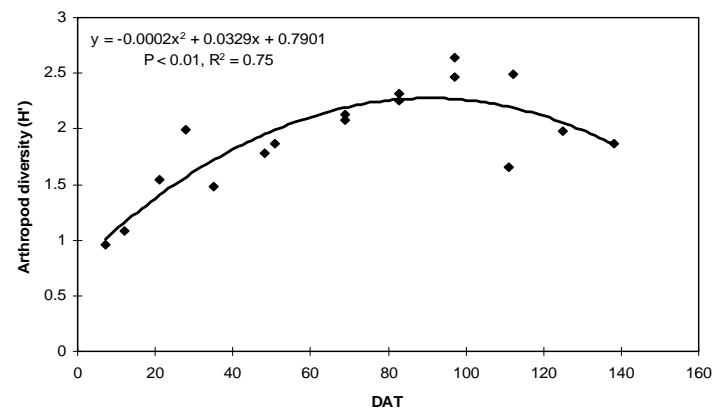

Figure 7. Relationship between crop age (DAT) and arthropod diversity $\left(\mathrm{H}^{\prime}\right)$ in the rice habitat.

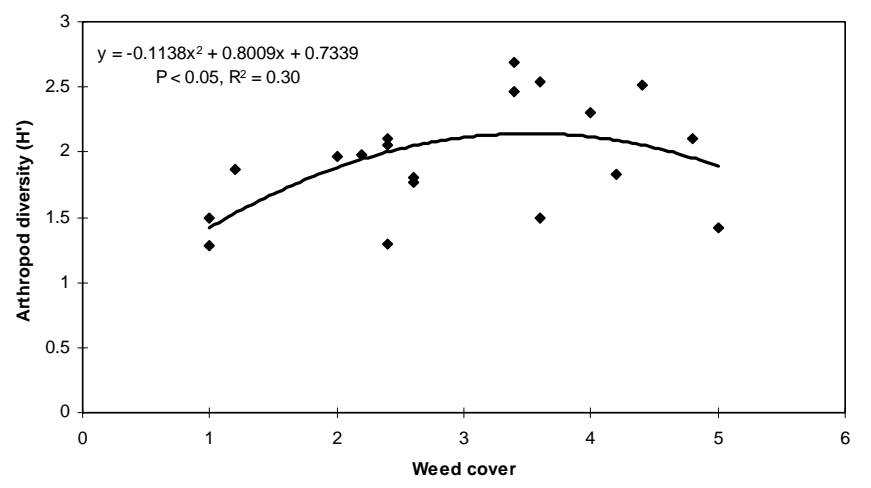

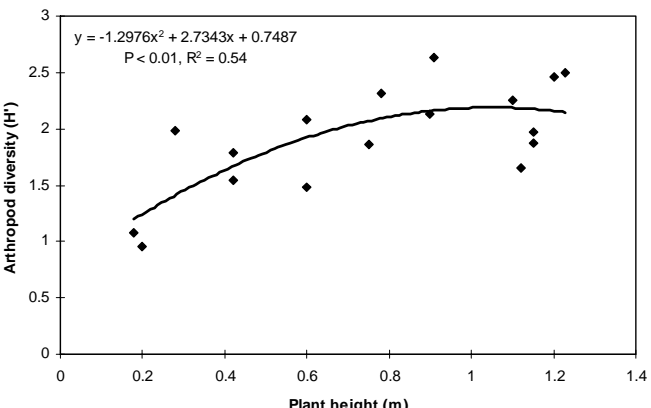

Figure 8. Relationship between rice plant height (m) and arthropod diversity $\left(\mathbf{H}^{\prime}\right)$.

Figure 9. Relationship
between weed cover in the
bunds and arthropod
diversity (H').

Figure 9. Relationship bunds and arthropod diversity $\left(\mathbf{H}^{\prime}\right)$

\section{DISCUSSION}

This study highlights the richness of the terrestrial arthropod fauna associated with an irrigated rice field ecosystem in Sri Lanka. The terrestrial arthropod fauna comprising 342 species recorded during the present study is higher than that documented by Heong et al., (1991) from rice fields in the Philippines, where a total of 212 species were recorded. Furthermore, the arthropod fauna documented included eight taxa (1 wasp and 7 spiders) previously not recorded from Sri Lanka, but recorded from other South-East Asian countries. The wasp Brachystegus decoratus Turner has been recorded from India (Krombein, 1998), while the spiders have been recorded from rice fields in Philippines (Barrion and Litsinger, 1995). The study also reflects the importance and the role of one single group of insects; the Order Hymenoptera with the largest number of species represented almost entirely by beneficial insects including natural enemies of paddy pest insects and pollinators. The richness of the predatory spider fauna inhabiting the rice fields is evident from their species composition, abundance and distribution within the rice ecosystem.

The guild structure of the arthropod fauna further emphasizes the importance of the predators (149 spp.) and parasitoids (46 spp.) that outnumbered the phytophagous rice pests (55 spp.). Thus, the natural enemies accounted for nearly $60 \%$ of all the terrestrial arthropod taxa collected. The composition of the rice field arthropod fauna, while highlighting the high biodiversity in a monoculture crop, confirms the long term stability of the rice agroecosystem with respect to pests and natural enemies. As is evident from the present study, the significant positive relationships between the pest insects and their natural enemies (predators and parasitoids) exhibit the natural balance that exists among arthropod guilds in the rice field ecosystem. A high species richness among arthropod natural enemies in rice ecosystems has been observed by previous researchers as well (Heong et al., 1991; Ooi and 
Shepard, 1994; Settle et al., 1996). In contrast to the relative paucity of natural enemies in irrigated rice fields of temperate countries (Perfect and Cook, 1994; Heong et al., 1991), the rich composition of arthropod predators and parasitoids of rice insect pests in tropical rice fields highlights the potential of natural biological control in such areas.

The spiders constituting the dominant predators inhabit the different strata of the rice plants and weeds, as well as the ground surface. They are considered important predators of the rice insect pests, especially of plant and leafhopper pests of rice (Ooi and Shepard, 1994). The bund weed cover provided an additional habitat to the terrestrial arthropod fauna in the rice fields. Bund weeds are inhabited by many species of predatory spiders and coccinellid beetles, while the tall weeds in particular provide resting sites for predatory Odonata. Importance of the bund weed cover was further confirmed by the significant relationships obtained between insect pests and their predators in bunds. Previous researchers have clearly stressed the importance of investigating the weed cover on rice field bunds, as reservoirs of natural enemies (Ooi and Shepard, 1994), especially for early arriving species such as spiders (Way and Heong, 1994). Thus, the results of the present study show that the weed cover on bunds provides suitable habitats for the survival of predators, and functions as a reservoir of natural enemies, especially during the fallow period. Since some weed species in bunds also provide a reservoir of alternate hosts for insect pests, proper management of weed cover in bunds may enhance control of pests, while promoting natural enemies. Partial slashing of weeds, as opposed to intense slashing, would enable preservation of predator habitats.

The phytophagous pest guild was represented and dominated by four major homopteran sap feeding pest species of rice, which cause direct damage to the rice plant, and are potential vectors of a variety of rice viral diseases. Amongst them, the brown planthopper (BPH), Nilaparvata lugens is known to cause major crop losses in rice growing regions of the world (Dyck and Thomas, 1979), including South India and Sri Lanka, where most virulent populations are found (Heong and Sogawa, 1994). The co-occurring white-backed plant hopper (WBPH), Sogatella furcifera, is also an important sap sucking pest (Kiritani, 1979). The green leafhoppers, Nephotettix virescens and $N$. nigropictus are known to transmit the virus which causes tungro disease of rice (Thresh, 1989). Amongst the sap feeding heteropteran pests inhabiting the field bunds, the dominance of the rice bug Leptocorisa oratorius could be attributed to the abundance of numerous graminaceous weeds (such as Echinochloa spp., Dactyloctenium aegyptium, Panicum repens and Eleusine indica ) which are known to act as alternate hosts of this pest (Rajapakse, 1996).

The existence of a natural balance between rice insect pests and their natural enemy guilds was clearly evident during the Yala cycle, where no pesticides were applied after transplanting. This aspect was further evident from the seasonal abundance of major rice insect pests and their specific arthropod natural enemies recorded during this study. For instance, Heong et al., (1990) reported that the mirid bug Cyrtorhinus lividipennis was found to predate on the eggs and nymphs of both leafhoppers and plant hoppers preferring mainly BPH eggs. Similarly, the trichogrammatid wasp Oligosita sp., has been documented as an important egg parasitoid of delphacids (Shepard et al., 1987). Hence, as observed during the Maha cycle, the increase in the population density of $C$. lividipennis and Oligosita sp. may be attributed to an increase in the abundance of the BPH and WBPH.

As the dominant group of scavengers in the rice fields, the Collembola are of potential interest as they are known to be an important source of prey for polyphagous predators (Alvarez et al., 1997). The presence of decaying organic matter, especially during the initial and later stages of a cultivation cycle enables the springtails to thrive in rice fields. They also were the dominant group of scavengers in the rice fields of the Philippines (Heong et al., 1991). Mukharji and Gupta (1971) recorded 12 species of Collembola from the rice fields in Varanasi, India that included three species documented during the present study. These authors also found that the springtails are more abundant in moist rice soil rich in organic matter as was observed during the present study. The marked decrease in the abundance of Collembola in the rice fields soon after pesticide applications indicates their potential as an important bio-indicator of pesticide usage. These findings support the work of Frampton (1997), who documented the potential of epigeic Collembola as indicators of pesticide side-effects in arable ecosystems.

The colonisation and succession of major arthropod taxa in the rice field habitat was observed to follow a uniform pattern in relation to the growth stages of the rice crop as well as the different phases of the rice field (Table 8). The 
early colonisation and build up of arthropod communities observed in the rice field proper were similar to those recorded by Heong et al., (1991), and Schoenly et al., (1996), where pest phytophages increased in numbers faster than predators and parasitoids, and where predators arrived faster than parasitoids. The dominance of predators during the ripening stage of the crop can be attributed to an increase in their spatial habitat in relation to the rice plant architecture as well as to an abundance of their prey. During the grain ripening stage, the thick growth of the rice plant provides innumerable niches for predatory spiders. Draining of the fields during the same period also creates new habitats by exposing the soil surface for spiders, ants and carabid beetles to colonise. Harvesting of the rice crop reduced or removed the vegetation inhabited by arthropods, resulting in a reduction in their populations.
The sustenance of the rich rice field arthropod communities amidst very dynamic short term changes in this man made ecosystem reflects the long term coexistence of the flora and fauna. This has been brought about by adaptations geared to rapid colonization and exploitation of available niches in the short term and the ability to sustain small populations in the long term under not so favourable conditions. The rice fields are a unique ecosystem in this respect.

The effect of pesticide use on rice insect pest populations and their natural enemies were clearly evident from this study. Compared to the predators, the faster recovery of insect pest populations after a pesticide induced reduction suggests that pesticides cause substantially higher mortality to predators than to pests. Spiders were found to be the major group of predators adversely affected by pesticide use.

Table 8. Major arthropod taxa in different stages/phases of the rice field.

\begin{tabular}{|c|c|}
\hline Stage/Phase & Major taxa which colonized \\
\hline $\begin{array}{l}\text { Field preparation } \\
\text { (Semi-aquatic) }\end{array}$ & $\begin{array}{l}\text { Predators: Pardosa pseudoannulata, Solenopsis spp., Camponotus spp., } \\
\text { Odontomachus spp., Paederus alternans, Euborellia spp., Liris spp., Delta } \\
\text { campeniformes, Tridactylus spp. } \\
\text { Phytophages (Visitors): Lepidoptera } \\
\text { Scavengers: Blatella germanica, Diptera }\end{array}$ \\
\hline Nursery (Aquatic) & $\begin{array}{l}\text { Phytophages (rice pests): Nephotettix spp, Recilia dorsalis, Baliothrips } \\
\text { biformis } \\
\text { Predators: Solenopsis spp, Camponotus spp, Paederus alternans, Plexippus } \\
\text { spp., P. pseudoannulata }\end{array}$ \\
\hline $\begin{array}{l}\text { Flooded fields } \\
\text { transplanting (Aquatic) }\end{array}$ & $\begin{array}{l}\text { Predators: Odonata, Microvelia spp, Mesovelia spp, Hydrometra greeni } \\
\text { Scavengers: Diptera }\end{array}$ \\
\hline $\begin{array}{l}\text { Active tillering } \\
\text { (Aquatic) }\end{array}$ & $\begin{array}{l}\text { Phytophages (rice pests): Orseolia oryzae, Cnaphalocrocis medinalis, } \\
\text { Sogatella furcifera, Nilaparvata lugens, Cofana spectra, Acrididae, } \\
\text { Chironomidae }\end{array}$ \\
\hline & $\begin{array}{l}\text { Predators: Tetragnatha spp., Opheonia spp, Dyschiriognatha spp., } \\
\text { Gryllidae. } \\
\text { Parasitoids: Mymaridae, Scelionidae } \\
\text { Scavengers: Collembola }\end{array}$ \\
\hline Booting (Aquatic) & $\begin{array}{l}\text { Phytophages (rice pests): Scirpophaga incertulas } \\
\text { Predators: Atypena spp, Argiope spp, Therididae, Oxyopidae, Cyrtorhinus } \\
\text { lividipennis, Conocephalus longipennis, Coccinellidae } \\
\text { Parasitoids: Trichogrammatidae }\end{array}$ \\
\hline Flowering (Aquatic) & $\begin{array}{l}\text { Phytophages (rice pests): Leptocorisa oratorius } \\
\text { Predators: Reduviidae } \\
\text { Phytophages (Visitors): Nomia spp. }\end{array}$ \\
\hline Milky Grain(Aquatic) & Phytophages (rice pests): L. oratorius, Pentatomidae \\
\hline Ripe Grain(Semi-aquatic) & Predators: Carabidae. \\
\hline Mature crop (Dry) & $\begin{array}{l}\text { Phytophages (rice pests): Coptotermes spp. } \\
\text { Predators: Formicidae }\end{array}$ \\
\hline Fallow period (Dry) & $\begin{array}{l}\text { Phytophages (rice pests): Cofana spectra, Nephotettix spp, Coptotermes } \\
\text { spp. } \\
\text { Predators: P. alternans, M. discolor, Therididae, Atypena spp. }\end{array}$ \\
\hline
\end{tabular}


The reduction of arthropod natural enemies and the resurgence of pest insects due to indiscriminate pesticide use has been emphasized by many researchers (Kiritani, 1979; Pingali and Roger,1995; Pingali and Gerpacio, 1997; Chelliah and Bharathi, 1994). The systemic insecticide carbofuran that was applied to the nursery during each cultivation cycle is a commonly used insecticide in rice cultivations throughout Sri Lanka. Khusakul et al., (1979) found carbofuran to be very effective in controlling rice stemborers without effecting hymenopteran parasitoids. However, populations of predatory spiders such as Tetragnatha spp., Oxyopes spp., Pardosa pseudoannulata, the mirid bug Cyrtorhinus lividippennis and damselflies were severely reduced. Lam and Soon (1994) observed a significant reduction in the populations of predatory coccinellid beetles (Micraspis spp.), C. lividipennis and a variety of spider species in rice fields, following the application of insecticides, where a $90 \%$ reduction in populations was recorded 3 - 5 days after application.

Heong et al., (1991) stated that besides the immediate environment, cropping patterns and cultivation practices, arthropod communities may vary with the rice varieties planted. However, during the present study, the influence of different rice varieties on the diversity of arthropods during two consecutive rice cultivation cycles was not evident. The changes in the arthropod community in a rice field appears to be largely governed by ecological changes that are thrust upon the rice ecosystem by the agronomic practices essential to rice cultivation.

In conclusion, the study highlights the fact that the composition and structure of the arthropod communities in a rice ecosystem are characterized by (1) a high turn over of species (2) rapid waves of colonization (3) presence of species well adapted to specific niches (4) presence of species tolerant to short lived, but drastic physical changes in the rice field and (5) species that are specific to a particular growth stage of the rice plant or particular phase of the rice field. The findings also highlight the existence of stable relationships between the rice insect pests and their arthropod natural enemies, under minimal biocide application. The populations of arthropod natural enemies in rice fields could be conserved and enhanced through the maintenance of a rich weed flora during the fallow period, management of weed communities on the bunds through partial slashing, and by minimal use of biocides when needed, to avoid economic damage by specific insect pests. Natural biological control which maintains the diversity and integrity of this manmade agro-ecosystem should be given prime importance in deciding environmentally safe and effective integrated pest management strategies. The role of biodiversity in the dynamics and management of insect pests of rice highlighted by Way and Heong (1994) is further substantiated by the present study.

\section{ACKNOWLEDGMENTS}

The study reported here, forms part of a larger study on the ecology and biodiversity in an irrigated rice field ecosystem, funded by the National Science Foundation (NSF) of Sri Lanka. The authors are grateful to Dr. Lionel Nugaliyadde formally of the Rice Research and Development Institute at Bathalagoda, Sri Lanka for providing logistical and technical support to carry out the project in Bathalagoda, Prof. C.H. Fernando (University of Waterloo, Canada) and the late Dr. Felix Amerasinghe (International Water Management Institute) for providing valuable references on the topic. Dr. J.W. Reid, the late Dr. K. V. Krombein and Dr. Beth Norden (formerly of the Smithsonian Institution, USA), Dr. Susan Batra (formerly of USDA. Beltsville), Dr. A. T. Barrion (International Rice Research Institute, Philippines), Dr. Masataka Sato (Nagoya Women's University, Japan), Dr. T. Hidaka (JICA Rice Pest Expert) and Dr. Robert Jackson (University of Canteburry, New Zealand) are gratefully acknowledged for confirming the identity of several arthopod species. Prof. R. O. Thattil (Faculty of Agriculture, University of Peradeniya, Sri Lanka) assisted with the statistical analysis of data. Mr.Thushara Ranasinghe assisted with the field work and sorting of the field collection, throughout the study period. .

\section{REFERENCES}

Alvarez, T., Frampton, G.K. and Goulson, D. (1997). Population dynamics of epigeic Collembola in arable fields: the importance of hedgerow proximity and crop type. Pedobiologia 41: $110-114$

Arida, G. S. and Heong, K. L. (1992). BlowerVac: A new suction apparatus for sampling rice arthropods. IRRN. 17 (6): 30-31.

Barrion, A. T. and Litsinger, J. A. (1994). Taxonomy of rice insect pests and their arthropod parasites and predators. In : E. A. Heinrichs (Ed.) 
Biology and management of rice insects, Wiley Eastern Ltd., India \& IRRI, Manila, Philippines. Pp 13-362.

Barrion, A. T. and Litsinger, J. A. (1995). Riceland spiders of South and South-East Asia. CAB International, UK \& IRRI, Philippines. PP 700 .

Chang, T.T. (1985). Crop history and genetic conservation - a case study. Iowa State Journal of Research 59: 425-455.

Chelliah, S., and Bharathi, M. (1994). Insecticide management in rice. In : E. A. Heinrichs (Ed.) Biology and Management of Rice Insects,. Wiley Eastern Ltd., India \& IRRI, Manila, Philippines. Pp. 657-680.

D'Abreira, B. (1998). The butterflies of Ceylon. Wildlife Heritage Trust, Colombo, Sri Lanka. Pp 221.

Dale, D. (1994). Insect pests of the rice plant Their biology and ecology. In : E. A. Heinrichs (Ed.) Biology and Management of Rice Insects, Wiley Eastern Ltd., India \& IRRI, Manila, Philippines. Pp 363-487.

De Fonseka, T. (1997). A Guide to the Dragonflies of Sri Lanka. Pp.195.

Dyck, V. A. and Thomas, B. (1979). The brown planthopper problem. In: Brown planthopper: threat to rice production in Asia. International Rice Research Institute, Los Banos, Philippines. Pp. 3-17

Fernando, C. H. (1977). Investigations on the aquatic fauna of tropical rice fields with special reference to South-East-Asia. Geo-Eco-Trop. 3: 169-188.

Frampton, G. K. (1997). The potential of Collembola as indicators of pesticide usage: evidence and methods from the UK arable ecosystem. Pedobiologia 41: 179-184.

Freund, R. J., and Littell, R. C. (1991). SAS (System for Regression (2nd Ed.). SAS Institute Inc., U. S. A. Pp.210.

Grist, D. H. (1965). Rice (4th Ed.). Longmans, Green \& Co. Ltd., London. Pp. 548.

Gunatilleke, G. A. and Somasiri, S. (1995). Rice growing ecosystems. In: Amarasiri, S. L., S. Nagarajah \& B.M.K. Perera (Eds.). Proceedings of the Rice Congress, 1990. Dept. of Agriculture, Sri Lanka. Pp. 1-16

Heckman, C.W. (1979). Rice field ecology in North East Thailand. Monogr. Biol. 34: 228.

Heong, K. L. and Sogawa, K. (1994). Rice insect pest management - critical issues. In: Teng, P. S., Heong, K. L. \& Moody, K. (Eds.) Advances in Rice Pest Science and Management. IRRI, Los Banos, Philippines.

Heong, K. L. (1990). Feeding rates of the rice leaffolder, Cnaphalocrocis medinalis (Lepidoptera : Pyralidae), on different plant stages. J. Agric. Entomol. 7 (2): 81-90.

Heong, K. L., Aquino, G. B. \& Barrion, A. T. (1991). Arthropod community structures of rice ecosystems in the Philippines. Bulletin of Entomological Research 81: 407-416.

Heong, K. L., Bleigh, S. and Lazaro, A. A. (1990). Predation of Cyrtorhinus lividipennis Reuter, on eggs of the green leafhopper and brown planthopper in rice. Res. Popul. Ecol. 32: 255-262.

Khusakul, V., Pattarasudhi, R. and Patirupanuson, P. H. (1979). Effects of granular insecticides on stem borers and their parasites and predators. Intl. Rice Res. Newsl. 4 (6):16-17.

Kiritani, K. (1979). Pest management in rice. Annual Review of Entomology 24: 279-312.

Kobayashi, M., Kudagamage, C. and Nugaliyadde, L. (1991). Hymenopteron parasitoids of the rice gall midge, Orseolia oryzae (Wood-Mason) in the early Maha season in Sri Lanka. JARQ, 25 (1): 65-68.

Kobayashi, M., Kudagamage, C. and Nugaliyadde, L. (1995). Distribution of larvae of Ophionea indica Thunberg (Carabidae), a predator of the rice gall midge, Orseolia oryzae (WoodMason) in paddy fields of Sri Lanka. JARQ, 29 (2): 89-93.

Krombein, K.V. (1998). Brachystegus decoratus (Turner) (Hymenoptera:Sphecidae), an Indian wasp new to Sri Lanka. Proc.Entomol.Soc. Wash.100 (4): 828.

Littell, R. C., Freund, R. J and Spector, P. S. (1991). SAS (System for Linear Models. SAS Institute Inc. U. S. A. 329 pp. 
Magurran, A. E.(1988). Ecological Diversity and its Measurement. Croom Helm Ltd, London.

Moran, V. C. and Southwood, T. R. E. (1982). The guild composition of arthropod communities in trees. Journal of Animal Ecology 51: 289-306.

Mukharji, S. P. and Gupta, G. P. (1971). Some soil arthropods collected from paddy fields at Varanasi.. J. Bombay Nat. Hist. Soc. 71 (2): 319321.

Nishida, T. and Torii, T. (1970). A Handbook of Field Methods for Research on Rice Stem Borers and their Natural Enemies. Blackwell Scientific Publications, Oxford.

Ooi, P. A. C. and Shepard, B. M. (1994). Predators and parasitoids of rice insects. In : E. A. Heinrichs (Ed.) Biology and management of rice insects, Wiley Eastern Ltd., India \& IRRI, Manila, Philippines. Pp. 613-656.

Otake, A., Somasunderam, P. H. and Abeykoon, M. B. (1976). Studies on populations of Sogatella furcifera Horvath and Nilaparvata lugens (Stal) (Hemiptera: Delphacidae) and their parasites in Sri Lanka. Appl. Ent. Zool. 11 (3) : 284-294.

Panabokke, C. R. (1996). Soils and agroecological environments of Sri Lanka. Natural Resources, Energy and Science Authority of Sri Lanka. Pp. 220.

Perera, N. P. (1980). Natural resources, settlements and land use. In: Fernando, C. H. (Ed.). Ecology and biogeography in Sri Lanka. Junk Publishers, The Hague. Pp.453 - 493.

Perfect, T. J. and Cook, A. G. (1994). Rice planthopper dynamics: a comparison between temperate and tropical tropical regions. In: Denno, R. F. \& T. J. Perfect (Eds.) Planthoppers, their ecology and management. Chapman \& Hall, London. Pp. 282-301.

Pingali, P. L. And Roger, P. A. (1995). Impact of pesticides on farmer health and rice environment. Kluwer academic publishers \& IRRI, Philippines.
Pingali, P. L. and Gerpacio, R. V. (1997). Living with reduced insecticide use for tropical rice in Asia. Food Policy 22 (2): 107-118.

Rajapakse, R.H.S. (1996). Survival of rice bug Leptocorisa oratorius on graminaceous weeds in a tropical forest environment in Southern Sri Lanka. Proc. IUFRO Symp. On impact of diseases and insect pests in tropical forests. Pp. 448-452.

Rajendram, G. F. and Devarajah, F. R. (1990). Survey of some insect pests and their predators in three districts of Sri Lanka. J. Natn. Sci. Coun. Sri Lanka 18 (1): 79-92.

Schoenly, K., Cohen, J. E., Heong, K. L., Litsinger, J. A., Aquino, G. B., Barrion, A. T. and Arida, G. (1996). Food web dynamics of irrigated rice fields at five elevations in Luzon, Philippines. Bulletin of Entomological Research 86 (4): 451460.

Settle, W.H., Ariawan, H., Astuti, E.T., Cayhana, W., Hakim, A.L., Hindayana, D., Lestari, A.S. and Pajarningsih, S. (1996). Managing tropical rice pests through conservation of generalist natural enemies and alternative prey. Ecology 77(7): 1975-1988.

Shepard, B. M., Barrion, A. T.and and Litsinger, J. A. (1987). Friends of the rice farmer: Helpful insects, spiders and pathogens. International Rice Research Institute, Los Banos, Philippines. Pp.136.

Thresh, J. M. (1989). Insect-borne viruses of rice and the green revolution. Tropical Pest Management 35 (3): 264-272.

Tikader, B. K. (1987). Handbook - Indian spiders. Zoological Survey of India. Pp. 251.

Way, M. J. and Heong, K. L. (1994). The role of biodiversity in the dynamics and management of insect pests of tropical irrigated rice: A review. Bulletin of Entomological Research 84: 567-587.

Wilson, M. R. \& Claridge, M. F. (1991). Handbook for the identification of leafhoppers and planthoppers of rice. CAB International, UK. Pp.142. 
Appendix 1. Taxonomic composition, feeding guild and habitats of the terrestrial arthropod fauna in the rice field ecosystem at Bathalagoda. Guild: Phyto - Phytophage (V) - visitor, (P) - rice pest; Pred Predator; Paras - Parasitoid; Scav - Scavenger. Habitat: FP - Field proper; B - Bund.

\begin{tabular}{|c|c|c|c|c|}
\hline $\begin{array}{l}\text { Class } \\
\text { Order }\end{array}$ & Family & Genus/Species & Guild & Habitat \\
\hline \multirow{51}{*}{$\begin{array}{l}\text { INSECTA } \\
\text { Hymenoptera }\end{array}$} & & & & \\
\hline & Apoidea & & & \\
\hline & Halictidae & Nomia nr. eburnigera & Phyto(V) & $\mathrm{B}$ \\
\hline & & Nomia $n r$. oxybeloides & Phyto(V) & $\mathrm{B}$ \\
\hline & & Nomia nr. strigata & Phyto(V) & $\mathrm{FP}, \mathrm{B}$ \\
\hline & & Nomia sp. A. & Phyto(V) & FP, B \\
\hline & & Nomiodes $n r$. variegata & Phyto(V) & $\mathrm{B}$ \\
\hline & & Sphecodes sp. & Phyto(V) & $\mathrm{B}$ \\
\hline & & Lasioglossum (Ctononomia) nr. cattalum. & Phyto(V) & $\mathrm{B}$ \\
\hline & Anthophoridae & Ceratina (Pithitis) binghami Cockerell & Phyto(V) & $\mathrm{B}$ \\
\hline & & Amegilla puttalama Strd. & Phyto(V) & $\mathrm{B}$ \\
\hline & Apidae & Apis cerana indica Fr. & Phyto(V) & $\mathrm{FP}, \mathrm{B}$ \\
\hline & & Apis florea Fr. & Phyto(V) & $\mathrm{FP}, \mathrm{B}$ \\
\hline & Megachilidae & Megachile nr. Gathela & Phyto(V) & B \\
\hline & & Megachile lanata Fabricius & Phyto(V) & $\mathrm{B}$ \\
\hline & & Heriades binghami Dover & Phyto(V) & $\mathrm{B}$ \\
\hline & & Coelioxys sp. & Phyto(V) & B \\
\hline & Formicoidea & & & \\
\hline & Formicidae & Camponotus sp. A. & Pred & FP, B \\
\hline & & Camponotus sp. B. & Pred & $\mathrm{FP}, \mathrm{B}$ \\
\hline & & Polyrachis sp. & Pred & $\mathrm{FP}, \mathrm{B}$ \\
\hline & & Lophomyrmex sp. & Pred & $\mathrm{FP}, \mathrm{B}$ \\
\hline & & Atta sp. & Phyto(P) & FP, B \\
\hline & & Solenopsis sp. & Pred & FP, B \\
\hline & & Pheidologeton sp. & Pred & $\mathrm{FP}, \mathrm{B}$ \\
\hline & & Odontomachus sp. & Pred & FP, B \\
\hline & & Leptogenys sp. & Pred & FP, B \\
\hline & Ichneumonoidea & & & \\
\hline & Ichneumonidae & Xanthopimpla flavolineata Cameron & Paras & FP, B \\
\hline & & Charops brachypterum (Cameron) & Paras & $\mathrm{FP}, \mathrm{B}$ \\
\hline & & Temelucha philippinensis (Ashmead) & Paras & FP, B \\
\hline & & Amauromorpha sp. & Paras & $\mathrm{FP}, \mathrm{B}$ \\
\hline & & Itolplectis sp. & Paras & $\mathrm{FP}, \mathrm{B}$ \\
\hline & Braconidae & Cotesia (Apantales) flavipes Cameron & Paras & $\mathrm{FP}, \mathrm{B}$ \\
\hline & & Cotesia sp. A. & Paras & FP, B \\
\hline & & Macrocentrus sp. & Paras & $\mathrm{FP}, \mathrm{B}$ \\
\hline & & Bracon sp. & Paras & $\mathrm{FP}, \mathrm{B}$ \\
\hline & & Opius sp. & Paras & $\mathrm{FP}, \mathrm{B}$ \\
\hline & & Snellenius sp. & Paras & $\mathrm{FP}, \mathrm{B}$ \\
\hline & Chalcidoidea & & & \\
\hline & Trichogrammatidae & Paracentrobia yasumatsui Subba Rao & Paras & $\mathrm{FP}, \mathrm{B}$ \\
\hline & & Oligosita sp. A. & Paras & $\mathrm{FP}, \mathrm{B}$ \\
\hline & & Oligosita sp. B. & Paras & FP, B \\
\hline & Eulophidae & Afrostocetus beatus (Perkins) & Paras & $\mathrm{FP}, \mathrm{B}$ \\
\hline & & Tetrastichus sp. & Paras & $\mathrm{FP}, \mathrm{B}$ \\
\hline & & Elasmus sp. & Paras & $\mathrm{FP}, \mathrm{B}$ \\
\hline & Mymaridae & Mymar taprobanicum Ward & Paras & $\mathrm{FP}, \mathrm{B}$ \\
\hline & & Gonatocerus sp. & Paras & FP, B \\
\hline & & Anagrus sp. & Paras & $\mathrm{FP}, \mathrm{B}$ \\
\hline & Chalcididae & Brachymeria lasus (Walker) & Paras & $\mathrm{FP}, \mathrm{B}$ \\
\hline & & Brachymeria sp. B. & Paras & FP, B \\
\hline
\end{tabular}




\begin{tabular}{|c|c|c|c|c|}
\hline & & Antrocephalus sp. & Paras & FP, B \\
\hline & Pteromalidae & Trichomalopsis sp. & Paras & $\mathrm{FP}, \mathrm{B}$ \\
\hline & Eupelmidae & Neanastatus oryzae Ferriere & Paras & FP, B \\
\hline & Evanioidea & & & \\
\hline & Gasteruptiidae & Gasteruption sp. & Paras & $\mathrm{FP}, \mathrm{B}$ \\
\hline & Proctotrupoidea & & & \\
\hline & Platygasteridae & Platygaster oryzae Cameron. & Paras & $\mathrm{FP}, \mathrm{B}$ \\
\hline & Scelionidae & Telenomus nr. triptus Nixon & Paras & $\mathrm{FP}, \mathrm{B}$ \\
\hline & & Telenomus rowani (Gahan) & Paras & $\mathrm{FP}, \mathrm{B}$ \\
\hline & & Gryon nixoni (Masner) & Paras & $\mathrm{FP}, \mathrm{B}$ \\
\hline & & Macroteleia crawfordi Keiffer & Paras & $\mathrm{FP}, \mathrm{B}$ \\
\hline & & Psix spp. & Paras & FP, B \\
\hline & Diapriidae & Trichopria sp. & Paras & $\mathrm{FP}, \mathrm{B}$ \\
\hline & Bethyloidea & & & \\
\hline & Bethylidae & Rhabdepyris sp. & Paras & $\mathrm{FP}, \mathrm{B}$ \\
\hline & Dryinidae & Haplogonatopus sp. & Paras & FP, B \\
\hline & & Pseudogonatopus sp. & Paras & $\mathrm{FP}, \mathrm{B}$ \\
\hline & Sphecoidea & & & \\
\hline & Sphecidae & Ammophila laevigata & Pred & $\mathrm{FP}, \mathrm{B}$ \\
\hline & & Sceliphron madraspatanum & Pred & FP, B \\
\hline & & Liris albopilosa Tsun. & Pred & $\mathrm{FP}, \mathrm{B}$ \\
\hline & & L. aurulenta & Pred & $\mathrm{FP}, \mathrm{B}$ \\
\hline & & L. flavipennis (Wms.) & Pred & $\mathrm{FP}, \mathrm{B}$ \\
\hline & & L. subtessellata (Sm.) & Pred & FP, B \\
\hline & & Larra simillima (Sm.) & Pred & $\mathrm{FP}, \mathrm{B}$ \\
\hline & & Bembecinus pusillus (Handl.) & Pred & $\mathrm{FP}, \mathrm{B}$ \\
\hline & & Brachystegus decoratus (Turner) & Pred & $\mathrm{FP}, \mathrm{B}$ \\
\hline & & Cerceris pulchra Cam. & Pred & $\mathrm{FP}, \mathrm{B}$ \\
\hline & & Cerceris sp. A. & Pred & $\mathrm{FP}, \mathrm{B}$ \\
\hline & & Alysson sp. & Pred & $\mathrm{FP}, \mathrm{B}$ \\
\hline & Scolioidea & & & \\
\hline & Scoliidae & Scolia picteti Sauss. & Paras & $\mathrm{FP}, \mathrm{B}$ \\
\hline & & Scolia affinis Guer. & Paras & $\mathrm{FP}, \mathrm{B}$ \\
\hline & Mutillidae & Petersenidia krombeini & Paras & $\mathrm{FP}, \mathrm{B}$ \\
\hline & Tiphiidae & Mesa petiolata (Sm.) & Paras & $\mathrm{FP}, \mathrm{B}$ \\
\hline & Vespoidea & & & \\
\hline & Eumenidae & Eumenes sp. & Pred & $\mathrm{FP}, \mathrm{B}$ \\
\hline & Vespidae & Ropalidia stigma (Smith) & Pred & $\mathrm{FP}, \mathrm{B}$ \\
\hline & & Delta campeniformes (Fabricius) & Pred & $\mathrm{FP}, \mathrm{B}$ \\
\hline & & Euodynerus sp. & Pred & $\mathrm{FP}, \mathrm{B}$ \\
\hline & Pompiloidea & & & \\
\hline & Pompilidae & Paracyphononyx incognitus (Cameron) & Pred & $\mathrm{FP}, \mathrm{B}$ \\
\hline Lepidoptera & Papilionidae & Papilio demoleus L. & Phyto(V) & B \\
\hline & & P. polytes L. & Phyto(V) & B \\
\hline & & Pachliopta hector L. & Phyto(V) & B \\
\hline & & P. aristolochiae Fabricius & Phyto(V) & B \\
\hline & & Graphium agamemnon L. & Phyto(V) & B \\
\hline & & Troides darsius Gray & Phyto(V) & B \\
\hline & Lycaenidae & Zizula hylax Fabricius & Phyto(V) & B \\
\hline & & Zizina otis Fabricius & Phyto(V) & $\mathrm{B}$ \\
\hline & & Zizeeria karsandra Moore & Phyto(V) & B \\
\hline & & Jamides celeno Cramer & Phyto(V) & $\mathrm{B}$ \\
\hline & & Amblypodia anita Hewitson & Phyto(V) & B \\
\hline & & Lampides boeticus L. & Phyto(V) & B \\
\hline & & Jamides lacteata de Niceville & Phyto(V) & B \\
\hline & & & Phyto(V) & B \\
\hline & Pieridae & Eurema hecabe L. & Phyto(V) & B \\
\hline & & E. blanda Boisduval & Phyto(V) & B \\
\hline
\end{tabular}




\begin{tabular}{|c|c|c|c|c|}
\hline & & E. brigitta Stol & Phyto(V) & $\mathrm{B}$ \\
\hline & & Leptosia nina Fanricius & Phyto(V) & B \\
\hline & & Catopsilia pyranthe L. & Phyto(V) & B \\
\hline & & C. pomona Fabricius & Phyto(V) & B \\
\hline & & Appias lyncida Cramer & Phyto(V) & B \\
\hline & & A. albina Boisduval & Phyto(V) & B \\
\hline & & Delias eucharis Drury & Phyto(V) & B \\
\hline & Nymphalidae & Ypthima ceylanica Hewitson & Phyto(V) & B \\
\hline & & Melanitis leda L. & Phyto(P) & FP, B \\
\hline & & Mycalesis perseus Fabricius & Phyto(V) & B \\
\hline & & M. mineus L. & Phyto(V) & B \\
\hline & & Tirumala septentrionis Butler & Phyto(V) & B \\
\hline & & T. limniace Cramer & Phyto(V) & B \\
\hline & & Parantica aglea Stoll & Phyto(V) & B \\
\hline & & Ideopsis similis L. & Phyto(V) & B \\
\hline & & Danaus chrysippus L. & Phyto(V) & B \\
\hline & & D. genutia Cramer & Phyto(V) & B \\
\hline & & Junonia iphita Cramer & Phyto(V) & B \\
\hline & & J. almana $\mathrm{L}$. & Phyto(V) & B \\
\hline & & J. atlites L. & Phyto(V) & B \\
\hline & & J. lemonias L. & Phyto(V) & B \\
\hline & & Euploea core Cramer & Phyto(V) & B \\
\hline & & E. klugii Moore & Phyto(V) & B \\
\hline & & Neptis hylas L. & Phyto(V) & B \\
\hline & & N. jumbah Moore & Phyto(V) & B \\
\hline & & Orsotriaena medus Fabricius & Phyto(V) & B \\
\hline & & Pantoporia hordonia Stoll & Phyto(V) & B \\
\hline & & Ariadne ariadne L. & Phyto(V) & B \\
\hline & & Phalanta phalantha Drury & Phyto(V) & B \\
\hline & & Elymnias hypermnestra L. & Phyto(V) & $\mathrm{B}$ \\
\hline & Hesperiidae & Pelopidas mathias Fabricius & Phyto(P) & $\mathrm{FP}, \mathrm{B}$ \\
\hline & & P. subochracea Fabricius & Phyto(P) & $\mathrm{FP}, \mathrm{B}$ \\
\hline & & Potanthus confuscius & Phyto(V) & B \\
\hline & & P. pseudomaesa & Phyto(V) & B \\
\hline & & Spalia galba & Phyto(V) & B \\
\hline & & Suastus gremius & Phyto(V) & B \\
\hline & Noctuidae & Spodoptera mauritia Boisd & Phyto(P) & $\mathrm{FP}, \mathrm{B}$ \\
\hline & Pyralidae & Sciropophaga incertulas (Walker) & Phyto(P) & FP, B \\
\hline & & S. innotata (Walker) & Phyto(P) & $\mathrm{FP}, \mathrm{B}$ \\
\hline & & Cnaphalocrocis medinalis (Guerner) & Phyto(P) & $\mathrm{FP}, \mathrm{B}$ \\
\hline & & Nymphula depunctalis Guerner & Phyto(P) & $\mathrm{FP}, \mathrm{B}$ \\
\hline Homoptera & Cicadellidae & Caloscarta capitata Stal. & Phyto(P) & $\mathrm{FP}, \mathrm{B}$ \\
\hline & & Nephotettix virescens (Distant) & Phyto(P) & FP, B \\
\hline & & N. nigropictus (Stal) & Phyto(P) & $\mathrm{FP}, \mathrm{B}$ \\
\hline & & N. parvus Ishihara \& Kawase & Phyto(P) & $\mathrm{FP}, \mathrm{B}$ \\
\hline & & N. sympatricus Ghauri & Phyto(P) & $\mathrm{FP}, \mathrm{B}$ \\
\hline & & Hecalus sp. & Phyto(P) & FP, B \\
\hline & & Exitianus sp. & Phyto(P) & $\mathrm{FP}, \mathrm{B}$ \\
\hline & & Empoascanara sp. & Phyto(P) & $\mathrm{FP}, \mathrm{B}$ \\
\hline & & Cofana spectra Distant & Phyto(P) & $\mathrm{FP}, \mathrm{B}$ \\
\hline & & Recilia dorsalis (Motschulsky) & Phyto(P) & FP, B \\
\hline & Delphacidae & Nilaparvata lugens (Stal) & Phyto(P) & $\mathrm{FP}, \mathrm{B}$ \\
\hline & & Sogatella furcifera (Horvath) & Phyto(P) & FP, B \\
\hline & Lophopidae & Pyrilla perpusilla (Walker) & Phyto(P) & FP, B \\
\hline & Aphididae & Aphis spiraecola & $\begin{array}{l}\text { Phyto } \\
\text { (V) }\end{array}$ & $\mathrm{B}$ \\
\hline & Pseudococcidae & Brevennia sp. & Phyto(P) & $\mathrm{FP}, \mathrm{B}$ \\
\hline Heteroptera & Alydidae & Leptocorisa oratorius Fabricius & Phyto(P) & $\mathrm{FP}, \mathrm{B}$ \\
\hline
\end{tabular}




\begin{tabular}{|c|c|c|c|c|}
\hline & Coreidae & Cletus punctiger (Dallas) & Phyto(P) & FP, B \\
\hline & & Riptortus linearis (Fabricius) & Phyto(P) & $\mathrm{FP}, \mathrm{B}$ \\
\hline & & Sirthenea flavipes (Stal) & Phyto(V) & $\mathrm{B}$ \\
\hline & Reduviidae & Polytoxus fuscovittatus (Stal) & Pred & $\mathrm{FP}, \mathrm{B}$ \\
\hline & & Polididus armatissimus Stal & Pred & $\mathrm{FP}, \mathrm{B}$ \\
\hline & & Scipinia horrida Stal & Pred & $\mathrm{FP}, \mathrm{B}$ \\
\hline & Pentatomiidae & Scotinophara lurida (Burmeister) & Phyto(P) & $\mathrm{FP}, \mathrm{B}$ \\
\hline & & Agonoscelis nubile (Hahn) & Phyto(P) & $\mathrm{FP}, \mathrm{B}$ \\
\hline & & Eysarcoris guttiger (Thunberg) & Phyto(P) & $\mathrm{FP}, \mathrm{B}$ \\
\hline & & Pygomenida bengalensis (Westwood) & Phyto(P) & $\mathrm{FP}, \mathrm{B}$ \\
\hline & & Glaucias virgineus (Stal) & Phyto(P) & $\mathrm{FP}, \mathrm{B}$ \\
\hline & & Nezara viridula (L.) & Phyto(P) & $\mathrm{FP}, \mathrm{B}$ \\
\hline & & Chrysocoris sp. & Phyto(P) & $\mathrm{FP}, \mathrm{B}$ \\
\hline & Miridae & Cyrtorhinus lividipennis Reuter & Pred & $\mathrm{FP}, \mathrm{B}$ \\
\hline & Pyrrocoridae & Disdercus cingulatus (Fabricius) & Phyto(V) & $\mathrm{B}$ \\
\hline & Nabidae & Nabis sp. & Pred & $\mathrm{FP}, \mathrm{B}$ \\
\hline & Lygaeidae & Geoceris ochropterus (Fieber) & Pred & $\mathrm{FP}, \mathrm{B}$ \\
\hline & & Pseudopachybrachius gutta (Dalh) & Phyto(V) & $\mathrm{B}$ \\
\hline & Anthocoridae & Deraecoris sp. & Pred & $\mathrm{B}$ \\
\hline Coleoptera & Coccinellidae & Harmonia octomaculata (Fabricius) & Pred & $\mathrm{FP}, \mathrm{B}$ \\
\hline & & Coccinella transversalis (Fabricius) & Pred & $\mathrm{FP}, \mathrm{B}$ \\
\hline & & Micraspis discolor (Fabricius) & Pred & $\mathrm{FP}, \mathrm{B}$ \\
\hline & & Brumoides suturalis (Fabricius) & Pred & $\mathrm{FP}, \mathrm{B}$ \\
\hline & & Liochrimus coccinella (Fabricius) & Pred & FP, B \\
\hline & Chrysomelidae & Dicladispa armigera (Oliver) & Phyto(P) & $\mathrm{FP}, \mathrm{B}$ \\
\hline & & Leptispa pygmaea Baly & Phyto(P) & $\mathrm{FP}, \mathrm{B}$ \\
\hline & & Haltica cyanea Web. & Phyto(P) & $\mathrm{FP}, \mathrm{B}$ \\
\hline & & Monolepta sp. & Phyto(P) & $\mathrm{FP}, \mathrm{B}$ \\
\hline & & Chaetocnema sp. & Phyto(V) & B \\
\hline & & Aulocophora sp. & Phyto(P) & $\mathrm{FP}, \mathrm{B}$ \\
\hline & & Colaspis sp. & Phyto(P) & $\mathrm{FP}, \mathrm{B}$ \\
\hline & & Hyphasis sp. & Phyto(V) & $\mathrm{B}$ \\
\hline & & Lema (S.str.) coromandeliana (Fabricius) & Phyto(V) & $\mathrm{B}$ \\
\hline & Carabidae & Ophionea (S.Str) indica (Thunberg) & Pred & $\mathrm{FP}, \mathrm{B}$ \\
\hline & & Ophionea (Setophionea) ishii Habu & Pred & $\mathrm{FP}, \mathrm{B}$ \\
\hline & & Clivina mustela Andrews & Pred & $\mathrm{FP}, \mathrm{B}$ \\
\hline & & Clivina castanea Westwood & Pred & $\mathrm{FP}, \mathrm{B}$ \\
\hline & & Tachys politus Motschulsky & Pred & $\mathrm{FP}, \mathrm{B}$ \\
\hline & & Tachys sp. & Pred & $\mathrm{FP}, \mathrm{B}$ \\
\hline & & Tachylopha ovata (Motschulsky) & Pred & $\mathrm{FP}, \mathrm{B}$ \\
\hline & & Stenolophus sp. & Pred & $\mathrm{FP}, \mathrm{B}$ \\
\hline & & Abacetus submetallicus (Nietner) & Pred & $\mathrm{FP}, \mathrm{B}$ \\
\hline & & Bradycellus sp. & Pred & $\mathrm{FP}, \mathrm{B}$ \\
\hline & & Hololeius ceylonicus (Nietner) & Pred & $\mathrm{FP}, \mathrm{B}$ \\
\hline & & Perigona nigriceps (Dejean) & Pred & $\mathrm{FP}, \mathrm{B}$ \\
\hline & & Mimocolliurius sp. & Pred & $\mathrm{FP}, \mathrm{B}$ \\
\hline & & Chlaenius sp. & Pred & $\mathrm{FP}, \mathrm{B}$ \\
\hline & & Submera latifrons (Dejean) & Pred & $\mathrm{FP}, \mathrm{B}$ \\
\hline & & Egadroma quinquepustulata Weidem & Pred & $\mathrm{FP}, \mathrm{B}$ \\
\hline & & Elaphropus sp. & Pred & $\mathrm{FP}, \mathrm{B}$ \\
\hline & & Anotylus sp. & Pred & $\mathrm{FP}, \mathrm{B}$ \\
\hline & Staphylinidae & Paederus alternans Walker & Pred & $\mathrm{FP}, \mathrm{B}$ \\
\hline & Curculionidae & Hydronomidius molitor Faust & Phyto(P) & $\mathrm{FP}, \mathrm{B}$ \\
\hline & & Echinocnemus oryzae Marshall & Phyto(P) & $\mathrm{FP}, \mathrm{B}$ \\
\hline & & Neocleonus sp. & Phyto(V) & $\mathrm{B}$ \\
\hline & & Myllocerus sp. & Phyto(V) & B \\
\hline & Elateridae & Aeoloderma brachmana (Candize) & Phyto(P) & $\mathrm{FP}, \mathrm{B}$ \\
\hline & Tenebrionidae & Formicomus braminus La Ferte & Pred & $\mathrm{FP}, \mathrm{B}$ \\
\hline
\end{tabular}




\begin{tabular}{|c|c|c|c|c|}
\hline & Meloidae & Mylabris sp. & Scav & FP, B \\
\hline \multirow[t]{10}{*}{ Orthoptera } & Acrididae & Gastrimaraus africanus det.sago & Phyto(P) & FP, B \\
\hline & & Oxya japonica (Thunberg) & Phyto(P) & $\mathrm{FP}, \mathrm{B}$ \\
\hline & & Acrotylus humbertianus Sauss. & Phyto(P) & FP, B \\
\hline & & Acrida exaltata Walker & Phyto(P) & $\mathrm{FP}, \mathrm{B}$ \\
\hline & & Gesonula punctifrons det sago & Phyto(P) & FP, B \\
\hline & & Atractomorpha crenulata (Fabricius) & Phyto(P) & $\mathrm{FP}, \mathrm{B}$ \\
\hline & Gryllidae & Metioche vittaticolis (Stal) & Pred & $\mathrm{FP}, \mathrm{B}$ \\
\hline & & Anaxipha longipennis (Serville) & Pred & $\mathrm{FP}, \mathrm{B}$ \\
\hline & Tridactylidae & Tridactylus sp. & Pred & FP, B \\
\hline & Tettigoniidae & Conocephalus longipennis (de Haan) & Pred & $\mathrm{FP}, \mathrm{B}$ \\
\hline \multirow[t]{21}{*}{ Diptera } & Cecidomyiidae & Orseolia aryzae (Wood-Mason) & Phyto(P) & FP, B \\
\hline & Muscidae & Atherigona oryzae Malloch & Phyto(P) & $\mathrm{FP}, \mathrm{B}$ \\
\hline & Ephydridae & Hydrellia philippina (Fallen) & Phyto(P) & FP, B \\
\hline & & Ochthera brevitibialis de Meijere & Pred & $\mathrm{FP}, \mathrm{B}$ \\
\hline & Anisopodidae & Sylvicola sp. & Scav & $\mathrm{FP}, \mathrm{B}$ \\
\hline & Ceratopogonidae & Culicoides sp. & Scav & $\mathrm{FP}, \mathrm{B}$ \\
\hline & Pipunculidae & Pipunculus mutillatus Loew. & Paras & FP, B \\
\hline & Tachinidae & Palexorista lucajus Walk. & Paras & $\mathrm{FP}, \mathrm{B}$ \\
\hline & & Phorochosoma sp. & Paras & $\mathrm{FP}, \mathrm{B}$ \\
\hline & & Prosopodopsis apendiculata de M. & Paras & $\mathrm{FP}, \mathrm{B}$ \\
\hline & Chironomidae & Chironomus sp. & Phyto(P) & FP, B \\
\hline & & Pentaneura sp. & Phyto(P) & FP, B \\
\hline & Tabanidae & Haematopota sp. A & Scav & FP, B \\
\hline & & Haematopota sp. $B$. & Scav & $\mathrm{FP}, \mathrm{B}$ \\
\hline & & Allograpta javana Wiedermann & Scav & FP, B \\
\hline & & Mesembrius bengalensis (Wiedermann) & Scav & FP, B \\
\hline & & Chrysops sp. & Scav & $\mathrm{FP}, \mathrm{B}$ \\
\hline & Platystomatidae & Poecilotraphera taeniata (Macquart) & Pred & $\mathrm{FP}, \mathrm{B}$ \\
\hline & Sarcophagidae & Amobia sp. & Scav & FP, B \\
\hline & & Senotainia sp. & Scav & FP, B \\
\hline & & Sarcophaga sp. & Scav & $\mathrm{FP}, \mathrm{B}$ \\
\hline \multirow[t]{19}{*}{ Odonata } & Libellulidae & Neurothomes tullia (Drury) & Pred & FP, B \\
\hline & & N. intermedia (Rambur) & Pred & $\mathrm{FP}, \mathrm{B}$ \\
\hline & & Orthetrum sabina (Drury) & Pred & FP, B \\
\hline & & O. pruinosum (Rambur) & Pred & $\mathrm{FP}, \mathrm{B}$ \\
\hline & & Pantala flaviscens (Fabricius) & Pred & $\mathrm{FP}, \mathrm{B}$ \\
\hline & & Diplocodes trivialis (Rambur) & Pred & FP, B \\
\hline & & Potamarcha congener (Rambur) & Pred & FP, B \\
\hline & & Crocothemis servilia (Drury) & Pred & $\mathrm{FP}, \mathrm{B}$ \\
\hline & & Trithemis festiva (Rambur) & Pred & FP, B \\
\hline & Gomphidae & Ictinogomphus rapax (Rambur) & Pred & $\mathrm{FP}, \mathrm{B}$ \\
\hline & Coenagrionidae & Ceriagrion coromandelianum (Fabricius) & Pred & FP, B \\
\hline & & C. cerinorubellum (Brauer) & Pred & $\mathrm{FP}, \mathrm{B}$ \\
\hline & & Ceriagrion sp. A. & Pred & FP, B \\
\hline & & Agriocnemis pygmaea (Rambur) & Pred & $\mathrm{FP}, \mathrm{B}$ \\
\hline & & Ischnura aurora (Brauer) & Pred & FP, B \\
\hline & & Pseudagrion sp. & Pred & $\mathrm{FP}, \mathrm{B}$ \\
\hline & Protoneuridae & Elattoneura caesia (Selys) & Pred & $\mathrm{FP}, \mathrm{B}$ \\
\hline & & Ellattoneura sp. & Pred & $\mathrm{FP}, \mathrm{B}$ \\
\hline & Lestidae & Lestes sp. & Pred & FP, B \\
\hline \multirow[t]{4}{*}{ Collembola } & Isotomidae & Isotomurus sp. & Scav & $\mathrm{FP}, \mathrm{B}$ \\
\hline & Sminthuridae & Sminthurides sp. & Scav & FP, B \\
\hline & Entomobryidae & Entomobrya sp. & Scav & FP, B \\
\hline & & Mesira sp. & Scav & FP, B \\
\hline \multirow[t]{2}{*}{ Strepsiptera } & Halictophagidae & Halictophagus sp. & Paras & FP, B \\
\hline & Elenchidae & Elenchus sp. & Paras & $\mathrm{FP}, \mathrm{B}$ \\
\hline Dermaptera & Carcinophoridae & Euborellia sp. & Pred & $\mathrm{FP}, \mathrm{B}$ \\
\hline
\end{tabular}




\begin{tabular}{|c|c|c|c|c|}
\hline Phasmatoidea & Phasmatidae & unidentified spp. & Pred & $\mathrm{B}$ \\
\hline \multirow[t]{2}{*}{ Thysanoptera } & Thripidae & Stenchaetothrips biformis (Bagnell) & Phyto(P) & $\mathrm{FP}, \mathrm{B}$ \\
\hline & & Haplothrips ganglbaueri Schumtz & Phyto(V) & $\mathrm{B}$ \\
\hline Blattoidea & Blattoidae & Blatella germanica $\mathrm{L}$. & Scav & $\mathrm{FP}, \mathrm{B}$ \\
\hline \multirow[t]{2}{*}{ Mantodea } & Mantidae & Archimantis sp. & Pred & $\mathrm{FP}, \mathrm{B}$ \\
\hline & & Unidentified sp. & Pred & $\mathrm{B}$ \\
\hline Neuroptera & Ascalaphidae & Suhpalacsa sp. & Pred. & $\mathrm{FP}, \mathrm{B}$ \\
\hline $\begin{array}{l}\text { Isoptera } \\
\text { ARACHNIDA }\end{array}$ & Rhinotermitidae & Coptotermes sp. & Phyto(P) & FP, B \\
\hline Acari & Phytoseiidae & $\begin{array}{l}\text { Amblyseius imbricatus Corpus et } \\
\text { Rimando }\end{array}$ & Pred & $\mathrm{FP}, \mathrm{B}$ \\
\hline \multirow[t]{46}{*}{ Araneae } & Araneidae & Argiope aemula (Walckenaer) & Pred & $\mathrm{FP}, \mathrm{B}$ \\
\hline & & A. catenulata (Doleschall) & Pred & $\mathrm{FP}, \mathrm{B}$ \\
\hline & & Neoscona molemensis Tikader \& Bal & Pred & $\mathrm{FP}, \mathrm{B}$ \\
\hline & & Neoscona nautica (L.Koch) & Pred & $\mathrm{FP}, \mathrm{B}$ \\
\hline & & Neoscona theisi (Walckenaer) & Pred & $\mathrm{FP}, \mathrm{B}$ \\
\hline & & Araneus sp.A. & Pred & $\mathrm{FP}, \mathrm{B}$ \\
\hline & & Araneus sp.B. & Pred & $\mathrm{FP}, \mathrm{B}$ \\
\hline & & Larinia sp. & Pred & $\mathrm{FP}, \mathrm{B}$ \\
\hline & & Gea sp. & Pred & $\mathrm{FP}, \mathrm{B}$ \\
\hline & & Eriovixia sp. & Pred & $\mathrm{FP}, \mathrm{B}$ \\
\hline & & Cyclosa sp. A. & Pred & FP, B \\
\hline & & Cyclosa sp.B & Pred & $\mathrm{FP}, \mathrm{B}$ \\
\hline & Tetragnathidae & Dyschiriognatha spp. & Pred & $\mathrm{FP}, \mathrm{B}$ \\
\hline & & Leucauge sp. A. & Pred & $\mathrm{FP}, \mathrm{B}$ \\
\hline & & Leucauge sp. B. & Pred & $\mathrm{FP}, \mathrm{B}$ \\
\hline & & Tylorida sp. & Pred & $\mathrm{FP}, \mathrm{B}$ \\
\hline & & Tetragnatha javana (Thorell) & Pred & $\mathrm{FP}, \mathrm{B}$ \\
\hline & & T. virescens Okuma & Pred & $\mathrm{FP}, \mathrm{B}$ \\
\hline & & T. vermiformis Emerton & Pred & $\mathrm{FP}, \mathrm{B}$ \\
\hline & & T. maxillosa Thorell & Pred & $\mathrm{FP}, \mathrm{B}$ \\
\hline & & T. ceylonica Cambridge & Pred & FP, B \\
\hline & & T. mandibulata Walckenaer & Pred & $\mathrm{FP}, \mathrm{B}$ \\
\hline & & T. nitens (Audouin) & Pred & $\mathrm{FP}, \mathrm{B}$ \\
\hline & Therididae & Theridion sp. & Pred & $\mathrm{FP}, \mathrm{B}$ \\
\hline & & Chrysso sp. & Pred & $\mathrm{FP}, \mathrm{B}$ \\
\hline & & Coleosoma sp. & Pred & FP, B \\
\hline & & Argyrodes sp. & Pred & $\mathrm{FP}, \mathrm{B}$ \\
\hline & & Steatoda sp. & Pred & $\mathrm{FP}, \mathrm{B}$ \\
\hline & & Enoplognatha sp. & Pred & $\mathrm{FP}, \mathrm{B}$ \\
\hline & & Gnathonarium sp. & Pred & $\mathrm{FP}, \mathrm{B}$ \\
\hline & Linyphiidae & Atypena sp. & Pred & $\mathrm{FP}, \mathrm{B}$ \\
\hline & Salticidae & Plexippus paykulli (Audouin) & Pred & $\mathrm{FP}, \mathrm{B}$ \\
\hline & & Plexippus sp. A. & Pred & $\mathrm{FP}, \mathrm{B}$ \\
\hline & & Carrhotus sp. & Pred & $\mathrm{FP}, \mathrm{B}$ \\
\hline & & Bianor sp. & Pred & FP, B \\
\hline & & Hasarius sp. & Pred & $\mathrm{FP}, \mathrm{B}$ \\
\hline & & Mymarachne plateleodes (O.P. - & Pred & $\mathrm{FP}, \mathrm{B}$ \\
\hline & & Cambridge) & Pred & $\mathrm{FP}, \mathrm{B}$ \\
\hline & & Phintella sp. & Pred & FP, B \\
\hline & & $\begin{array}{l}\text { Harmochirus brachiatus (Thorell). } \\
\text { Simaetha sp. }\end{array}$ & Pred & FP, B \\
\hline & Thomisidae & Runcinia sp. A & Pred & $\mathrm{FP}, \mathrm{B}$ \\
\hline & & Runcinia sp. B. & Pred & $\mathrm{FP}, \mathrm{B}$ \\
\hline & & Thomisus sp. A. & Pred & $\mathrm{FP}, \mathrm{B}$ \\
\hline & & Thomisus sp. B. & Pred & $\mathrm{FP}, \mathrm{B}$ \\
\hline & & Thomisus sp. C. & Pred & $\mathrm{FP}, \mathrm{B}$ \\
\hline & Lycosidae & Pardosa pseudoannulata (Boes. \& & Pred & FP, B \\
\hline
\end{tabular}




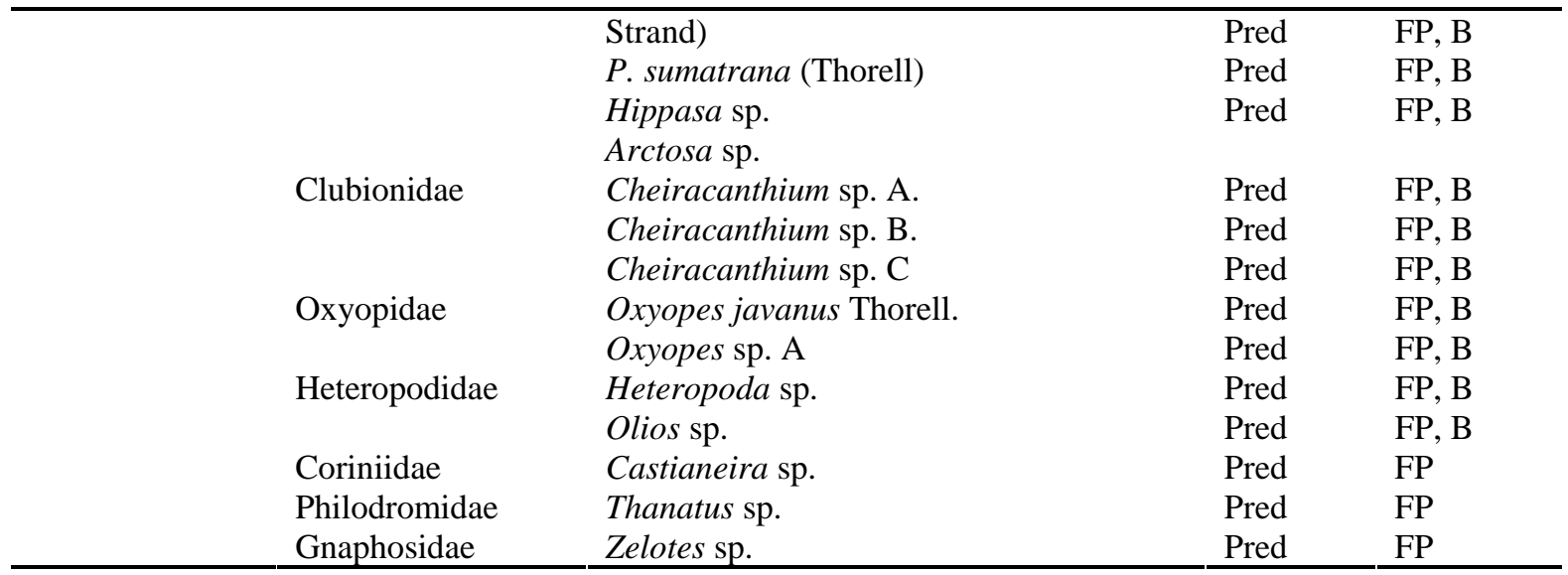

